\title{
Prediction of the Thermal Conductivities of Wood Based on an Intelligent Algorithm
}

\author{
Shiyu Zhou, ${ }^{\mathrm{a}, *}$ Xiaoxia Yang, ${ }^{\mathrm{b}}$ Yandong Zhang, ${ }^{\mathrm{b}}$ Xiaoping Liu, ${ }^{\mathrm{b}}$ and Yucheng Zhou ${ }^{\mathrm{b}}$ \\ For thermal comfort and energy-saving performance, a floor-heating \\ method is superior to conventional heating modes, e.g., radiator, fan coil, \\ etc. The floor-heating method has been developed to be a primary indoor \\ heating form. Wood is the most common floor surface material. Due to the \\ anisotropy of wood, it is difficult to obtain a general theoretical formula for \\ its thermal physical properties. In this paper, intelligent algorithms were \\ adopted to predict thermal conductivities of wood. First, the study \\ elaborated frequently used testing methods of thermal conductivity. Next, \\ 130 types of common wood species were measured to form a database \\ of thermal properties. With this database, intelligent algorithms were used \\ to make predictions. For the thermal conductivity predictions that were \\ conducted with support vector machine, the degree of fit between the \\ predicted results and the measured results was not less than 0.87 ( $k$-fold \\ validation). This study validated the feasibility of the usage of the intelligent \\ algorithm for the research and prediction of the thermal conductivities of \\ wood.
}

Keywords: Wood; Floor heating; Support Vector machine; Thermal conductivity

Contact information: a: School of Thermal Engineering, Shandong Jianzhu University, Jinan, Shandong 250101 China; $b$ : School of Information and Electrical Engineering, Shandong Jianzhu University, Jinan, Shandong 250101 China; *Corresponding author: zhou-1sy@163.com

\section{INTRODUCTION}

Since the supplying water temperature of a floor heating system is lower than that of a conventional heating system, such as a radiator, its energy consumption can be provided by renewable energies, e.g., solar energy, air source, and shallow geothermal energy. This characteristic allows floor heating systems to save greater amounts of energy, leading to its popularity. The study by Márquez et al. (2017) compared and analyzed the heating effects of different end forms of heating systems, i.e., fan-coil, floor heating, and a combination of the two. The results showed that a floor heating system is superior in terms of both energy consumption and indoor comfort. Zhou and He (2015) conducted experiments on wooden floor heating systems with different heat storage materials and different heating pipes. Research by Shin et al. (2015) showed that the floor surface temperature distribution of oak wood was more even than other covering panels, such as linoleum, which means that wooden surfaces can provide a more comfortable indoor heating environment. The heating performance of wooden floors is closely related to the thermal properties of wood. The recent studies about this theme have concentrated on the thermal conductivity of wood. The publications have been primarily divided into theoretical studies and experimental studies:

1) Theoretical studies include model formulas and empirical formulas, e.g., calculation models of the basic structural units of wood. Research involving the calculation 
model of the effective thermal conductivity of wood has gradually developed from the earlier empirical formula to the calculation model of the basic structural units of wood. For example, in the study conducted by Thunman and Leckner (2002), measurable parameters were employed, e.g., density, moisture content, and shrinkage, to calculate the effective thermal conductivity of wood. They also developed a calculation model of the effective thermal conductivity at different combustion stages. A study by Guo et al. (2013) was based on the linear heat source model, which numerically calculated the effective thermal conductivity and specific heat capacity of bulk wood particles by the least square method. According to the experimental and numerical results, the empirical relationships between the effective thermal conductivity of wood particles and the water content, as well as the porosity were obtained. The results showed that the thermal conductivity had nothing to do with the size of the wood particles. Meanwhile, the empirical relationship between the specific heat capacity and the water content was obtained.

2) Experimental studies have been primarily conducted at the macroscale and microstructural levels. At the macroscale level, the studies primarily have concentrated on the effective thermal conductivity (neglecting the wood structure and composition). Wood is a typical porous material, and the heat transfer process in wood is the result of the heat transfer in the solid, liquid, and air phases that are present in the wood. Therefore, the thermal conductivity of porous materials such as wood is usually defined as an effective thermal conductivity or an apparent thermal conductivity. At the microscale level, the relevant studies have extended from the effective thermal conductivity to the real thermal conductivity. These studies have concentrated on the thermal properties of wood elements, such as the thermal conductivity of the cell walls. The study by Vay et al. (2013), focused on the heat conductivity properties of wood from a cellular view via scanning thermal microscopy (SThM). It was found that heat conductibility along the axis direction of the wood cell was higher than that of the cross-section direction. Fan et al. (2006) established a fractal dimension model of the effective thermal conductivity of horizontal grain wood, which was validated with experiments conducted via an improved transient plane source measurement method. Afterwards, Laguiela et al. (2015) measured the axial and radial heat conductivity of different wood specimens via the hot-disk transient technique. Their study demonstrated that the heat transfer rate was greatly affected by the direction of the wood grain. Since the measurements were conducted while the wood was in the drying state, moisture percentage effects were not considered.

In this study, 130 wood specimens, belonging to different families, were tested with a thermal constant analyzer in order to measure their thermal conductivities. Then, an intelligent model was established using support vector machines to predict the thermal conductivities of the tested wood specimens.

\section{EXPERIMENTAL}

\section{Measuring Equipment and Theory}

Experimental apparatus

The experiment was conducted with a thermal constant analyzer (TPS2200) produced by Hot Disk located in Gothenburg, Sweden, as shown in Fig. 1a. The analyzer can measure the volume specific heat, thermal conductivity, and thermal diffusion coefficient of different materials, e.g., metal, wood, plastic, etc. Since there is a mathematical relationship between the thermal conductivity and thermal diffusion 
coefficient, the two parameters can be measured with the same probe, as shown in Fig. 1b. The device is also equipped with a vessel for testing heat capacity, which is not figured in the following text.

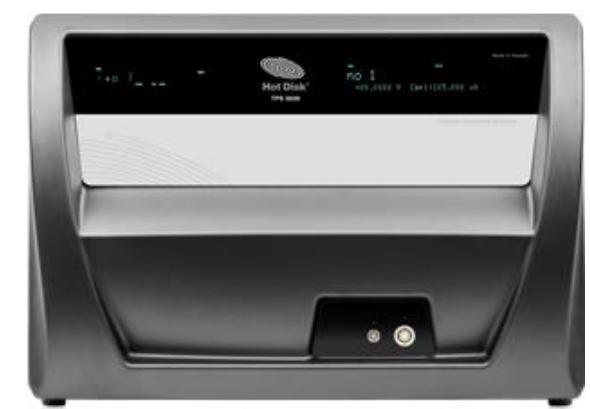

(a) Thermal constant analyzer (TPS2200)

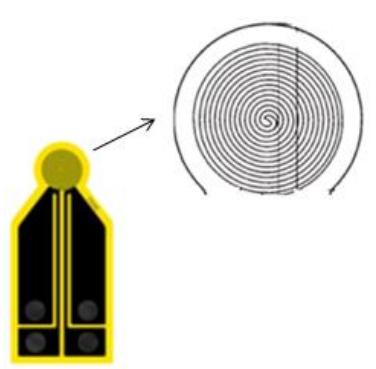

(b) Polyimide coated probe

Fig. 1. Experimental apparatus

\section{Transient plane source method}

The thermal conductivity and thermal diffusion coefficient were determined based on the transient plane source (TPS) method. Figure 2 is the test sketch map, and as shown, the probe was clamped above and below the tested specimen.

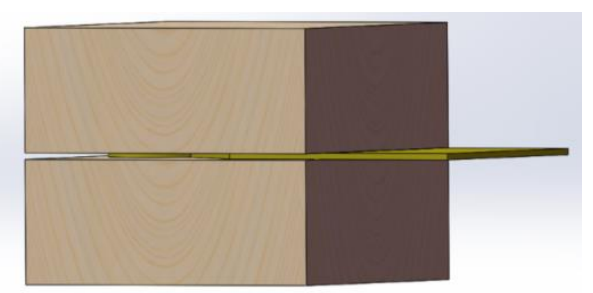

Fig. 2. Sketch map of the thermal property measurement testing procedure

The specimens were processed into two parts with the same square shape prior to testing. As depicted in $\mathrm{He}$ (2005), the temperature distribution of the probe along with time and space can be expressed according to Eq. 1,

$$
T(\vec{r}, t)=T_{0}+\int_{0}^{t} \int_{V^{\prime}} \frac{Q\left(\vec{\varepsilon}, t^{\prime}\right)}{\rho c} \times \frac{1}{[4 \pi \alpha(t-t)]^{\frac{3}{2}}} \times \exp \left(-\frac{(\vec{r}-\vec{\varepsilon})^{2}}{4 \alpha(t-t)}\right) d^{3} \vec{\varepsilon} d t^{\prime}
$$

where $r$ is the radius, $t$ is the time, $Q=Q(\vec{r}, t)$ is a function of space and time, $Q$ is the power dissipation per unit volume $\left[\mathrm{J} /\left(s \cdot \mathrm{m}^{3}\right)\right], T_{0}$ is the initial temperature, $\alpha$ is the thermal diffusion coefficient, $\rho$ is the density, $c$ is the thermal capacity, and $V$ is the heat source volume. Equation 1 can be simplified according to Eq. 2,

$$
T(\vec{r}, t)=T_{0}+\frac{Q_{0} / \rho c}{(4 \pi \alpha t)^{\frac{3}{2}}} \exp \left(-\frac{\left(\vec{r}-\vec{r}_{0}\right)^{2}}{4 \alpha t}\right)
$$

where $Q_{0}$ is the power of the heat source at the initial time $\left[\mathrm{J} /\left(\mathrm{s} \cdot \mathrm{m}^{3}\right)\right]$. The mathematical relationship between the thermal conductivity and thermal diffusion coefficient is shown in Eq. 3,

$$
\alpha=\lambda / \rho
$$


As shown in Fig. 1b, the probe is a double helical structure and provides constant heating power. Therefore, the probe can be simplified into a series of isometric concentric circles for analysis purposes, in order to simplify the calculation. For a probe with a cylinder number of $m$ and a maximum radius of $a$, the length of the metal wire is calculated according to Eq. 4,

$$
L=\sum_{l=1}^{n} 2 \pi l \frac{a}{m}=(m+1) \pi a
$$

On the basis of the above simplified analysis (Eq. 4), one of the single rings was taken for analysis. In the cylindrical coordinate, the coordinates of any point on the sample surface can be expressed as $\boldsymbol{p}=(r, \theta, z)$ and the coordinates of any point on the metal ring can be written as $\boldsymbol{q}=\left(r^{\prime}, \theta^{\prime}, z^{\prime}\right)$. There is an equality relationship between the two coordinates, as demonstrated in Eq. 5,

$$
(\boldsymbol{p}-\boldsymbol{q})^{2}=r^{2}+r^{\prime 2}+\left(z-z^{\prime}\right)^{2}-2 r r^{\prime} \cos \left(\theta-\theta^{\prime}\right)
$$

At the plane of $z^{\prime}=0$ on the cylindrical coordinate grid, temperature variation of the sample surface can be written as Eq. 6,

$$
T(r, \theta, z, t)-T_{0}=\frac{2 \pi b Q_{0} e^{-\left(r^{2}+b^{2}+z^{2}\right) /(4 \alpha t)}}{\rho c(4 \pi \alpha t)^{\frac{3}{2}}} I_{0}\left(\frac{r b}{2 \alpha t}\right)
$$

where $I_{0}(x)=\frac{1}{2 \pi} \int_{0}^{2 \pi} e^{x \cos \theta} d \theta=\frac{1}{2 \pi} \int_{0}^{2 \pi} e^{x \sin \theta} d \theta$ is the first type of correctional Bessel function with zero order and $b$ is the radius of a single ring.

The output power of a single ring is supposed to be constant; therefore, when $u\left(t^{\prime}\right)$ is the unit step function, the mathematical equation of the output power is shown in Eq. 7,

$$
Q=Q_{0} \delta\left(r^{\prime}-b\right) \delta\left(z^{\prime}\right) u\left(t^{\prime}\right)
$$

Integration should be made towards to the output power of a single ring and the probe power can be formulated according to Eq. 8,

$$
Q=Q_{0} \sum_{i=1}^{m} \delta\left(r^{\prime}-\frac{i a}{m}\right) \delta\left(z^{\prime}\right) u\left(t^{\prime}\right)
$$

Since the probe is defined at the surface of $z^{\prime}=0$, the temperature rise equation of the probe surface can be written as Eq. 9,

$$
\Delta T(r, \tau)=\int_{0}^{\tau} \frac{Q_{0} I_{0} \sum_{i=1}^{m} i^{2} \exp \left(-\left(\frac{r^{2}}{a^{2}}+i^{2} / m^{2}\right) /\left(4 \sigma^{2}\right)\right) r}{2 \pi^{\frac{3}{2}} b m(m+1) \alpha \sigma^{2}} d \sigma
$$

where $\sigma=\frac{\alpha\left(t-t^{2}\right)}{b^{2}}$ represents the integration variable and $\tau=\frac{\sqrt{\alpha t}}{b}$ is the dimensionless time constant. By searching for the mean values of $\Delta \bar{T}(r, \tau)$, the temperature rise function can be formulated as Eq. 10,

$$
\Delta \bar{T}(\tau)=\frac{Q_{0}}{\pi^{3 / 2} b \lambda} D(\tau)
$$

where $D(\tau)$ is given by Eq. 11 ,

$$
D(\tau)=\frac{1}{m^{2}(m+1)^{2}} \int_{0}^{\tau} \frac{d \sigma}{\sigma^{2}} \sum_{k=1}^{m} k \sum_{l=1}^{m} l \exp \left(-\left(k^{2}+l^{2}\right) /\left(4 \sigma^{2} m^{2}\right)\right) \times I_{0}\left(\frac{k l}{2 m^{2} \sigma^{2}}\right)
$$


It can be seen from Eq. 10 that there is a proportional relationship between the average surface temperature rise function of the probe $\Delta \bar{T}(\tau)$ and function of $D(\tau)$. When using the thermal constant analyzer, the thermal conductivity $(\lambda)$ can be computed with an equation between $\Delta \bar{T}(\tau)$ and $D(\tau)$ where $D(\tau)$ is the function of $\tau$. Therefore, when variables such as the number of wire loops is fixed, the value of $D(\tau)$ can be computed with $\tau$. In addition, $\Delta \bar{T}(\tau)$ is the function of $\tau$, which can be calculated during the heating process. The computation theory can be clearly elaborated with the above formulations. However, there are also shortcomings that exist in the calculation process. It can be concluded from the above analysis that $D(\tau)$ cannot be directly obtained, because the value of $\tau$ is decided by the thermal diffusion coefficient $(\alpha)$, heating time $(t)$, and probe radius (b), but the thermal diffusion coefficient is unknown, i.e., it needs to be measured. Therefore, it can only be computed via the iteration method, which is a time-consuming and complicated process. Therefore, in subsequent work it is intended to adopt the intelligent method for data processing and prediction works.

\section{Data Collection and Preprocessing}

Experimental data collection

This experiment measured 130 species of wood, which belonged to 39 different families (Table S1). The experimental specimen samples were processed from the original specimens, whose size was $210 \mathrm{~mm}$ x $105 \mathrm{~mm}$ x $20 \mathrm{~mm}$ (length by width by thickness). Figure 3(a) shows the processed specimen for measuring thermal conductivity and thermal diffusion coefficient, which was $50 \mathrm{~mm}$ x $50 \mathrm{~mm}$ x $20 \mathrm{~mm}$ (length by width by thickness). These specimens had been oven-dry to remove moisture before each test. So the influence of moisture content in the measured values was avoided.

Since the study was conducted under the context that applying wood floor to the floor heating system, the measurement directions were defined as shown in Fig. 3(b), rather than the real axial and radial directions of the wood. In this study, the two directions were defined according to the pavement of wood floor, the direction perpendicular to the floor was defined as 'Perpendicular', while the direction parallel to the floor is defined as 'Parallel'. Thermal conductivities of the two directions were measured for the reason that 'Perpendicular' thermal conductivity affects the heat release to the room, which will determine the indoor temperature distribution, while 'Parallel' thermal conductivity affects the heat diffusion along the floor, which will determine the temperature uniformity of the floor.

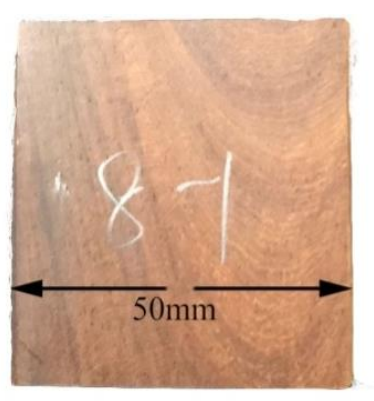

(a) The processed specimens
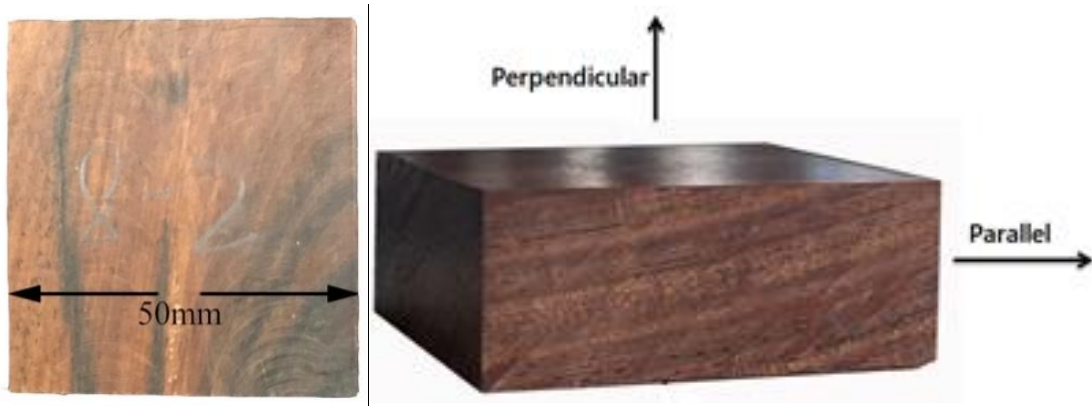

(b) Definition of the two measurement directions

Fig. 3. Specimens for measuring the thermal conductivity 


\section{Data preprocessing}

It was stated in the above section that the thermal properties of wood can be computed from the transient temperature data. Therefore, it is necessary to extract features that can reflect the temperature-changing characteristics. For the study of the thermal conductivity, transient temperature rise diagram is necessary, as shown in Fig. 4.

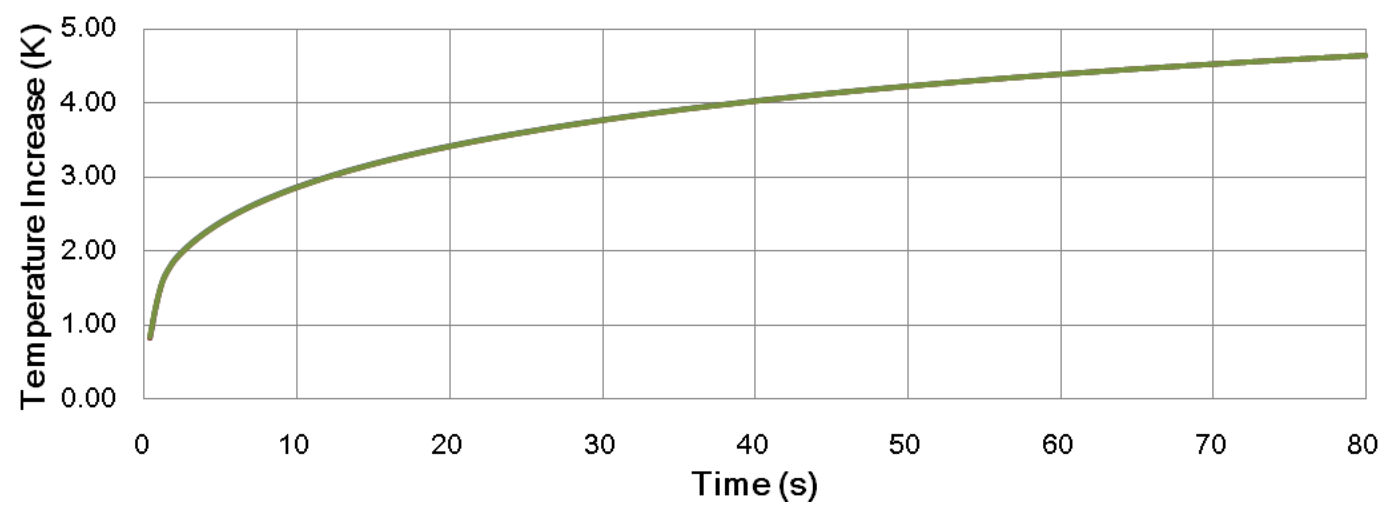

Fig. 4. Transient temperature rise diagram of anisotropy thermal conductivity (Monterey pine)

According to the suggestions from the Hot Disk company, the number of gathered temperature data points of each test should be approximately 200 . As described by the study objective in the first section, intelligent models for predicting the thermal properties of wood needed to be constructed in this study. If 200 data points are all set as model inputs, then it is almost impossible to obtain a valid and efficient model. In order to consider the regularity of the temperature change, feature extraction should be conducted towards to the temperature data. As shown in Fig. 4, the temperature curve was similar to the water temperature variations in the thermal response test (TRT) (Gehlin 2002). The data processing method of TRT, i.e., a logarithmic curve, was adopted for feature extraction, and the detailed linear fitting equation is shown as Eq. 12,

$$
\Delta T=A \ln (t)+B
$$

where $\Delta T$ is the temperature increment, $[\mathrm{K}] ; t$ is the time, $[\mathrm{s}]$; and $A$ and $B$ are the coefficients that were extracted from the temperature process data. The measured data of 130 kinds of wood were processed with the above formula (Eq. 12). All of the degrees of fitness $\left(\mathrm{R}^{2}\right)$ values were larger than 0.98 and the partial fitting results are plotted in the following diagrams (as shown in Fig. 5).

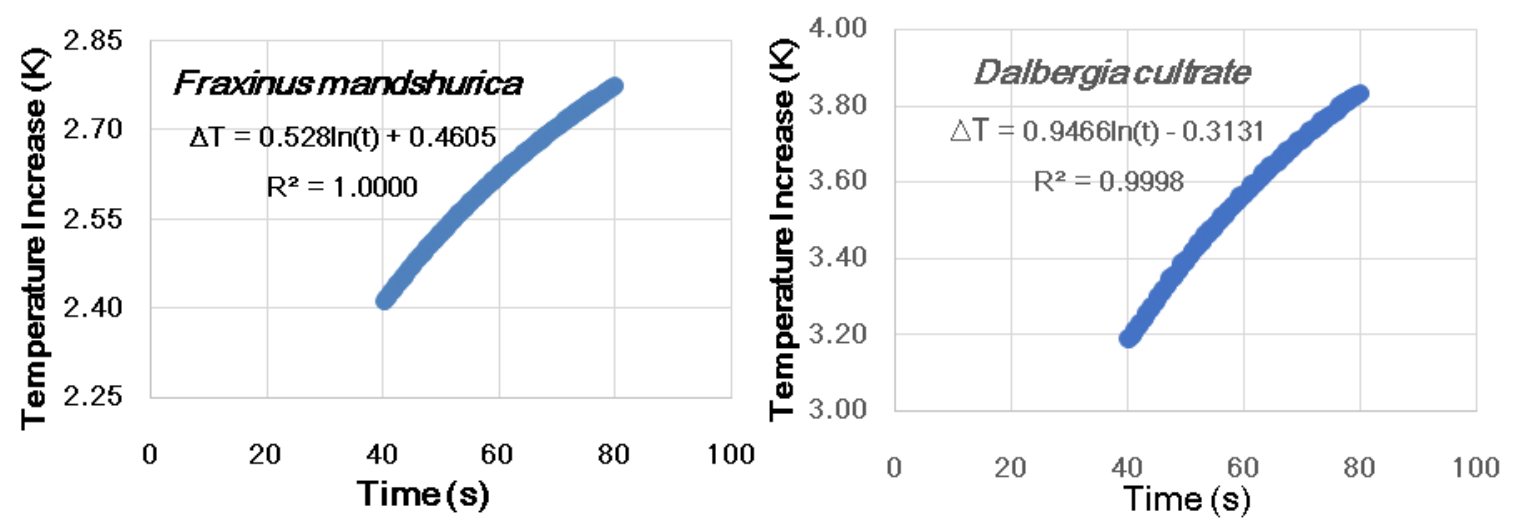

Fig. 5. Transient temperature rise scatter diagrams of different specimens 
Evaluation of the model accuracy should be calculated with several error indexes, e.g., the mean relative error $(M R E)$, the max relative error $(M A E)$, the mean square error $(M S E)$, and the absolute fraction of variance $\left(\mathrm{R}^{2}\right)$. The formulations of the above error indexes are expressed as Eqs. 15 through 18, respectively.

$$
\begin{aligned}
& M R E=\frac{1}{n} \sum_{i-1}^{n} \frac{\left|X_{c}(i)-X_{r}(i)\right|}{\left(X_{r-m a x}-X_{r-m i n}\right)} \times 100 \% \\
& M A E=\max _{i}\left(\frac{\left|X_{C}(i)-X_{r}(i)\right|}{\left(X r-m i n_{r-m a x}\right.} \times 100 \%\right) \\
& M S E=\sqrt{\frac{1}{n} \sum_{i-1}^{n} \frac{\left|X_{C}(i)-X_{r}(i)\right|}{\left(X_{r-m a x}-X_{r-m i n}\right)}} \times 100 \% \\
& R^{2}=1-\frac{\sum_{i=1}^{n}\left(X_{C}(i)-X_{r}(i)\right)^{2}}{\sum_{i=1}^{n}\left(X_{C}(i)-X_{C-m e a n}\right)^{2}}
\end{aligned}
$$

where $X_{c}$ is the output of the model, $X_{c-\text { mean }}$ is the average output of the model, $X_{r}$ is the experimental value, $X_{r-\max }$ is the maximum experimental value, and $X_{r-\min }$ is the minimum experimental value.

There are usually two validation ways, e.g., holdout validation and k-fold validation. For holdout validation: the data is split into training set and testing set, and then the model is trained and tested separately; while for k-fold validation, which is also called cycle validation. In the data preprocessing progress, the data is split into $k$ subsets averagely. Then the training and testing processes are conducted for $k$ times. In each time, one subset is defined as testing set for once, while the rest $k-1$ subsets are defined as training set. In turn, every subset can be treated as testing set for once. The prediction errors of each time are averaged to denote the final validation errors of the model.

\section{Intelligent Algorithms}

Many kinds of intelligent algorithms have been developed for the prediction or classification work in the last decades, such as Artificial Neural Network (ANN), Support Vector Machines (SVM), Adaptive Network-based Fuzzy Inference System (ANFIS) and Radial Basis Neural Network (RBN), etc. In these intelligent algorithms, SVM is commonly recognized to be suitable for the process of small data set. Because the number of experimental data is not so big, SVM was adopted for the prediction work in this study.

SVM is a machine learning algorithm basing on the statistical learning theory. Its principle is to construct the optimal separating hyperplane by mapping the input vector into a high-dimensional feature space according to the prior selected non-linear operator. SVM was born in the 90s of the last century; since then, it has been applied into more and more widely fields, such as predictions of outdoor/indoor temperature, wind speed, solar radiation, etc. (Paniagua-Tineo et al. 2011; Cai et al. 2015; Mohandes et al. 2004; Chen et al. 2011).

\section{RESULTS AND DISCUSSION}

\section{Models for Predicting Thermal Conductivity}

As mentioned in the above text, both 'Perpendicular' and 'Parallel' values of thermal conductivity need to be studied. Therefore, two separate models were trained in order to predict each of the two conductivity values. The two models have same input 
parameters, e.g., the sample density, together with the slope term $(A)$ and intercept term $(B)$ from Eq. 12. Although the two thermal conductivities were trained as outputs of two separate SVM models, their data was measured under the same testing conditions. The experiments were repeated 3 times and conducted under the following conditions: a heating power of $50 \mathrm{~mW}$ and an application period of $80 \mathrm{~s}$. There were 390 sets of data generated from the experiment (as shown in Table S2), in which 360 of the sets were picked out at random to train the SVM model, while the remaining 30 sets were gathered for testing.

In the k-fold validations, the $k$ value was selected as 13 , meaning that the whole data was divided into 13 subsets averagely after the data sequence was disturbed, so as to keep the random selection of the training data. And then 13 times of training and validation process were conducted for each model. For the training parameters of SVM model, their values were given as 'svmtrain(y_1_train,x_train,'-s 4 -t 2 -c 50 -g 180')'.

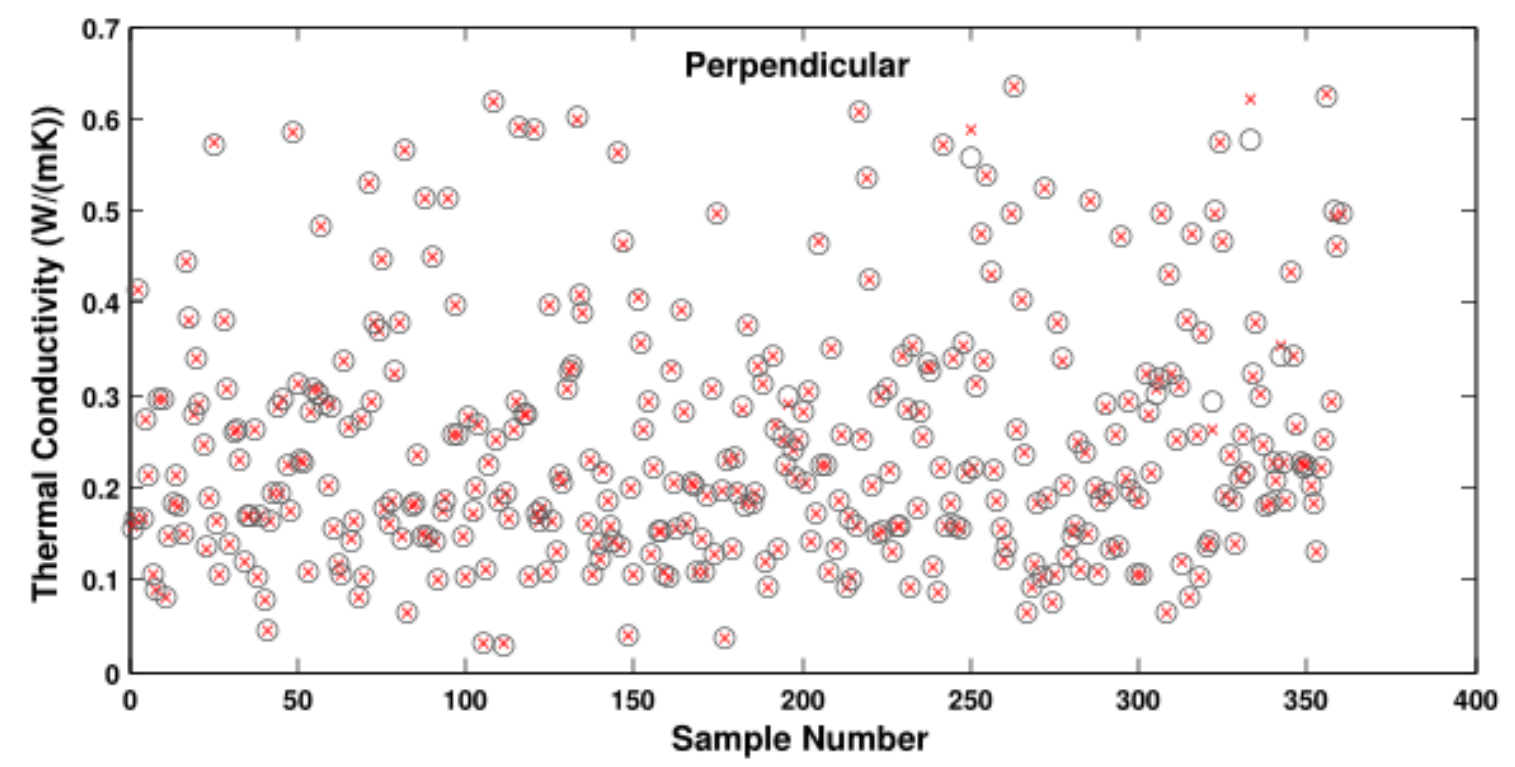

Fig. 6. Training results of the Perpendicular thermal conductivity

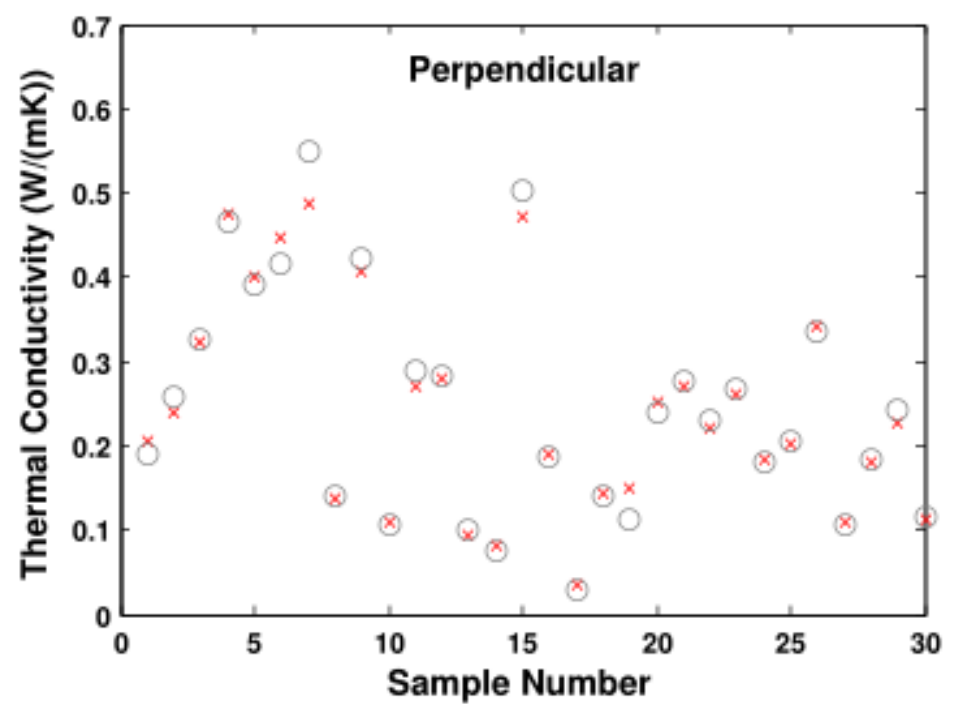




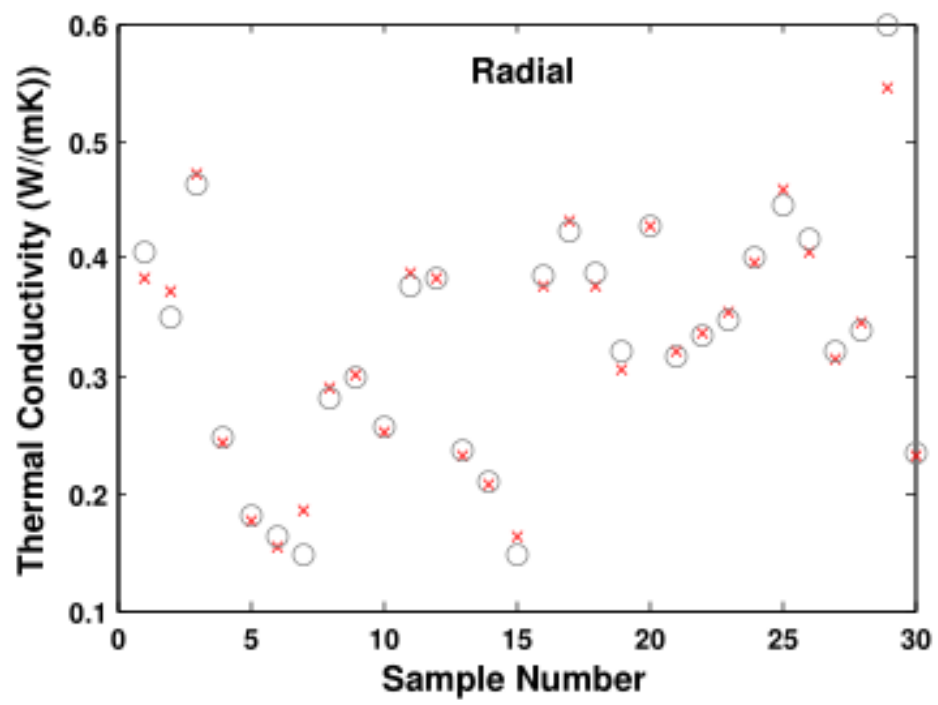

Fig. 7. Validation results of the two thermal conductivities

The model prediction results are listed in Figs. 6 and 7. In these figures, the ' $x$ ' means the output of SVM model, and ' $O$ ' means an experimental value. The horizontal axis represents the sample number, while the vertical axis represents the thermal conductivity, whose unit is $\mathrm{W} /(\mathrm{m} \cdot \mathrm{K})$. Training results of the Perpendicular thermal conductivity are not shown here to save space. Good coincidence between prediction value and experimental value can be found in the figures. The detailed prediction errors are given in Table 1, which shows that the holdout validation results were superior to k-fold validation results. For both of the two validation methods, the degree of fitness of the training data sets was as high as 0.99 , while the degree of fitness of the testing data sets was 0.87 or higher. The results demonstrated that the model was effective for an anisotropic thermal conductivity module.

Table 1. Prediction Errors of Thermal Conductivity

\begin{tabular}{|c|c|c|c|c|c|c|}
\hline \multicolumn{2}{|c|}{ Thermal Conductivity } & Data Set & MRE\%) & MAE $(\%)$ & MSE $(\%)$ & $R^{2}$ \\
\hline \multirow{3}{*}{$\begin{array}{c}\text { holdout } \\
\text { validation }\end{array}$} & $\begin{array}{c}\text { Perpen- } \\
\text { dicular }\end{array}$ & Training data & 0.1271 & 7.1687 & 0.4348 & 0.9993 \\
\cline { 2 - 7 } & Parallel & Testing data & 2.2473 & 12.0598 & 2.4356 & 0.9821 \\
\cline { 3 - 7 } & & Training data & 0.1202 & 3.1695 & 0.2580 & 0.9996 \\
\hline \multirow{3}{*}{$\begin{array}{c}\text { k-fold } \\
\text { validation }\end{array}$} & \multirow{2}{*}{$\begin{array}{c}\text { Perpen- } \\
\text { dicular }\end{array}$} & Training data & 2.2393 & 11.5298 & 2.2198 & 0.9789 \\
\cline { 2 - 7 } & Parallel & Testing data & 4.1355 & 6.7599 & 0.4078 & 0.9994 \\
\cline { 3 - 7 } & & Training data & 0.1264 & 29.8905 & 5.5189 & 0.8940 \\
\cline { 3 - 7 } & & Testing data & 5.0247 & 31.3020 & 5.3212 & 0.8710 \\
\hline
\end{tabular}




\section{CONCLUSIONS}

1. The thermal properties of 130 species of wood that belonging to different families were tested with a Hot Disk thermal constant analyzer to generate the initial training database. The prediction works were then conducted towards to these woods based on intelligent algorithm.

2. SVM was adopted for the prediction of the thermal conductivity. In order to simplify the calculation process, feature extraction was adopted and separate models for predicting the Perpendicular and the Parallel thermal conductivity (relative to the floor) were established. The testing degrees of fitness of the two models both were at least 0.87 , while holdout validation results were even better.

3. The success prediction of thermal conductivity with inputs of term A and B validated the fact that there may exists a mathematical relationship between thermal conductivity and $\boldsymbol{l n}(\boldsymbol{t})$, not only with $\boldsymbol{D}(\boldsymbol{\tau})$, although the specific equations has not been found.

\section{REFERENCE CITED}

Cai, Q., Wang, W., and Wang, S. (2015). "Application of indoor temperature prediction based on SVM and BPNN," Control \& Decision Conference, 2883-2887.

DOI:10.1109/CCDC.2015.7162418

Chen, J. L., Liu, H. B., Wu, W., and Xie, D. (2011). "Estimation of monthly solar radiation from measured temperatures using support vector machines - A case study," Renewable Energy 36(1), 413-420. DOI: 10.1016/j.renene.2010.06.024

Fan, L.-W., Hu, Y.-C., Tian, T., and Yu, Z.-T. (2006). "The prediction of effective thermal conductivities perpendicular to the fibres of wood using a fractal model and an improved transient measurement technique," International Journal of Heat and Mass Transfer 49(21-22), 4116-4123. DOI: 10.1016/j.ijheatmasstransfer.2006.03.027

Gehlin, S. (2002). Thermal Response Test Method Development and Evaluation, Ph.D. Dissertation, Lulea University of Technology, Luleå, Sweden

Guo, W., Lim, C. J., Bi, X., Sokhansanj, S., and Melin, S. (2013). "Determination of effective thermal conductivity and specific heat capacity of wood pellets," Fuel 103, 347-355. DOI:10.1016/j.fuel.2012.08.037

He, Y. (2005). "Rapid thermal conductivity measurement with a hot disk sensor: Part 1. Theoretical considerations," Thermochimica Acta 436(1-2), 122-129. DOI:10.1016/j.tca.2005.07.003

Lagüela, S., Bison, P., Peron, F., and Romagnoni, P. (2015). "Thermal conductivity measurements on wood materials with transient plane source technique," Thermochimica Acta 600, 45-51. DOI:10.1016/j.tca.2014.11.021

Márquez, A. A., López, J. M. C., Hernández, F. F., Muñoz, F. D., and Andrés, A. C. (2017). "A comparison of heating terminal units: Fan-coil versus radiant floor, and the combination of both," Energy and Buildings 138, 621-629.

DOI:10.1016/j.enbuild.2016.12.092

Mohandes, M. A., Halawani, T. O., Rehman, S., and Hussain, A. A. (2004). "Support vector machines for wind speed prediction," Renewable Energy 29(6), 939-947.

DOI: $10.1016 /$ j.renene.2003.11.009

Paniagua-Tineo, A., Salcedo-Sanz, S., Casanova-Mateo, C., Ortiz-Garcia, E. G., Cony, 
M. A., and Hernandez-Martin, E. (2011). "Prediction of daily maximum temperature using a support vector regression algorithm," Renewable Energy 36, 3054-3060. DOI: 10.1016/j.renene.2011.03.030

Shin, M. S., Rhee, K. N., Ryu, S. R., Yeo, M. S., and Kim, K. W. (2015). "Design of radiant floor heating panel in view of floor surface temperatures," Building and Environment 92, 559-577. DOI: 10.1016/j.buildenv.2015.05.006

Thunman, H., and Leckner, B. (2002). "Thermal conductivity of wood - Models for different stages of combustion," Biomass and Bioenergy 23(1), 47-54. DOI:10.1016/S0961-9534(02)00031-4

Vay, O., Obersriebnig, M., Müller, U., Konnerth, J., and Gindl-Altmutter, W. (2013). "Studying thermal conductivity of wood at cell wall level by scanning thermal microscopy (SThM)," Holzforschung 67(2), 155-159. DOI:10.1515/hf-2012-0052

Zhou, G., and He, J. (2015). "Thermal performance of a radiant floor heating system with different heat storage materials and heating pipes," Applied Energy 138(15), 648-660. DOI:10.1016/j.apenergy.2014.10.058

Article submitted: August 27, 2020; Peer review completed: October 18, 2020; Revised version received and accepted: November 26, 2020; Published: December 21, 2020. DOI: 10.15376/biores.16.1.1161-1185 


\section{APPENDIX}

Table S1. Detailed List of the Wood Specimens Measured in Experiment

\begin{tabular}{|c|c|c|c|c|c|}
\hline No. & Latin name & Family & No. & Latin name & Family \\
\hline 1 & $\begin{array}{l}\text { Pterocarpus } \\
\text { macrocarpus }\end{array}$ & Papilionaceae & 66 & Khaya sp. & Meliaceae \\
\hline 2 & Pterocarpus pedatus & Papilionaceae & 67 & $\begin{array}{c}\text { Eusideroxylon } \\
\text { zwageri }\end{array}$ & Lauraceae \\
\hline 3 & $\begin{array}{c}\text { Pterocarpus } \\
\text { erinaceus }\end{array}$ & Papilionaceae & 68 & $\begin{array}{c}\text { Spirostachys } \\
\text { africana }\end{array}$ & Euphorbiaceae \\
\hline 4 & Dalbergia latifolia & Papilionaceae & 69 & $\begin{array}{l}\text { Guibourtia } \\
\text { conjugata }\end{array}$ & Caesalpiniaceae \\
\hline 5 & $\begin{array}{c}\text { Dalbergia frutescens } \\
\text { var. tomentosa }\end{array}$ & Papilionaceae & 70 & Terminalia sp. & Combretaceae \\
\hline 6 & Pterocarpus indicus & Papilionaceae & 71 & $\begin{array}{l}\text { Triplochiton } \\
\text { scleroxylon }\end{array}$ & Sterculiaceae \\
\hline 7 & $\begin{array}{c}\text { Dalbergia } \\
\text { melanoxylon }\end{array}$ & Papilionaceae & 72 & Dryobalanops sp. & Dipterocarpaceae \\
\hline 8 & $\begin{array}{c}\text { Dalbergia } \\
\text { cochinchinensis }\end{array}$ & Papilionaceae & 73 & Berlinia sp. & Caesalpiniaceae \\
\hline 9 & Dalbergia bariensis & Papilionaceae & 74 & Koompassia sp. & Caesalpiniaceae \\
\hline 10 & Dalbergia oliveri & Papilionaceae & 75 & Hevea brasiliensis & Euphorbiaceae \\
\hline 11 & Dalbergia retusa & Papilionaceae & 76 & $\begin{array}{c}\text { Aucoumea } \\
\text { klaineana }\end{array}$ & Burseraceae \\
\hline 12 & Millettia stuhlmannii & Papilionaceae & 77 & Calophyllum sp. & Guttiferae \\
\hline 13 & Dalbergia louvelii & Papilionaceae & 78 & $\begin{array}{c}\text { Excentrodendron } \\
\text { hsienmu }\end{array}$ & Tiliaceae \\
\hline 14 & Dalbergia cultrata & Papilionaceae & 79 & Pericopsis elata & Papilionaceae \\
\hline 15 & Diospyros celebica & Ebenaceae & 80 & Betula alnoides & Betulaceae \\
\hline 16 & Cassia siamea & Caesalpiniaceae & 81 & $\begin{array}{l}\text { Pterocarpus } \\
\text { angolensis }\end{array}$ & Papilionaceae \\
\hline 17 & Baphia nitida & Papilionaceae & 82 & Sindora sp. & Caesalpiniaceae \\
\hline 18 & Bulnesia sp. & Zygophyllaceae & 83 & Shorea sp. & Dipterocarpaceae \\
\hline 19 & Cordia sp. & Boraginaceae & 84 & Swintonia sp. & Anacardiaceae \\
\hline 20 & Combretum imberbe & Combretaceae & 85 & Pometia sp. & Sapindaceae \\
\hline 21 & $\begin{array}{c}\text { Swartzia } \\
\text { madagascariensis }\end{array}$ & Papilionaceae & 86 & Ochroma sp. & Bombacaceae \\
\hline 22 & Ulmus sp. & Ulmaceae & 87 & Platymiscium sp. & Papilionaceae \\
\hline 23 & $\begin{array}{l}\text { Pterocarpus } \\
\text { tinctorius }\end{array}$ & Papilionaceae & 88 & Dicorynia sp. & Caesalpiniaceae \\
\hline 24 & $\begin{array}{c}\text { Colophospermum } \\
\text { mopane }\end{array}$ & Caesalpiniaceae & 89 & $\begin{array}{l}\text { Marmaroxylon } \\
\text { racemosum }\end{array}$ & Mimosoideae \\
\hline 25 & Gluta sp. & Anacardiaceae & 90 & $\begin{array}{c}\text { Loxopterygium } \\
\text { sagotii }\end{array}$ & Anacardiaceae \\
\hline 26 & Streblus sp. & Moraceae & 91 & Tabebuia sp. & Bignoniaceae \\
\hline 27 & Phoebe sp. & Lauraceae & 92 & Andira sp. & Papilionaceae \\
\hline 28 & $\begin{array}{l}\text { Platycladus } \\
\text { orientalis }\end{array}$ & Cupressaceae & 93 & Humiria balsamifera & Humiriaceae \\
\hline 29 & Lindera sp. & Lauraceae & 94 & Diplotropis sp. & Papilionaceae \\
\hline 30 & $\begin{array}{l}\text { Myroxylon } \\
\text { balsamum }\end{array}$ & Papilionaceae & 95 & Brosimum sp. & Moraceae \\
\hline
\end{tabular}




\begin{tabular}{|c|c|c|c|c|c|}
\hline 31 & $\begin{array}{l}\text { Guibourtia } \\
\text { tessmannii }\end{array}$ & Caesalpiniaceae & 96 & Martiodendron sp. & Caesalpiniaceae \\
\hline 32 & Pterocarpus soyauxii & Papilionaceae & 97 & $\begin{array}{l}\text { Vouacapoua } \\
\text { americana }\end{array}$ & Caesalpiniaceae \\
\hline 33 & Microberlinia sp. & Caesalpiniaceae & 98 & Manilkara sp. & Sapotaceae \\
\hline 34 & $\begin{array}{c}\text { Paraberlinia } \\
\text { bifoliolata }\end{array}$ & Caesalpiniaceae & 99 & Platonia insignis & Guttiferae \\
\hline 35 & Intsia sp. & Caesalpiniaceae & 100 & Hymenaea sp. & Caesalpiniaceae \\
\hline 36 & Tectona grandis & Verbenaceae & 101 & Diospyros sp. & Ebenaceae \\
\hline 37 & Peltogyne sp. & Caesalpiniaceae & 102 & Prunus sp. & Rosaceae \\
\hline 38 & $\begin{array}{l}\text { Entandrophragma } \\
\text { cylindricum }\end{array}$ & Meliaceae & 103 & Xylia sp. & Mimosoideae \\
\hline 39 & Mangifera sp. & Anacardiaceae & 104 & $\begin{array}{l}\text { Terminalia } \\
\text { tomentosa }\end{array}$ & Combretaceae \\
\hline 40 & Lophira alata & Ochnaceae & 105 & Aglaia sp. & Meliaceae \\
\hline 41 & Fraxinus sp. & Oleaceae & 106 & Afzelia sp. & Caesalpiniaceae \\
\hline 42 & $\begin{array}{c}\text { Fraxinus } \\
\text { mandshurica }\end{array}$ & Oleaceae & 107 & Swietenia sp. & Meliaceae \\
\hline 43 & Quercus sp. & Fagaceae & 108 & Xanthostemon sp. & Myrtaceae \\
\hline 44 & Quercus sp. & Fagaceae & 109 & Berchemia discolor & Rhamnaceae \\
\hline 45 & $\begin{array}{c}\text { Caesalpinia } \\
\text { paraguariensis }\end{array}$ & Caesalpiniaceae & 110 & $\begin{array}{c}\text { Guibourtia } \\
\text { coleosperma }\end{array}$ & Caesalpiniaceae \\
\hline 46 & Juglans sp. & Juglandaceae & 111 & Machaerium sp. & Papilionaceae \\
\hline 47 & Dipteryx sp. & Papilionaceae & 112 & Samanea saman & Mimosoideae \\
\hline 48 & Bombax sp. & Bombacaceae & 113 & Campnosperma sp. & Anacardiaceae \\
\hline 49 & Buchenavia sp. & Combretaceae & 114 & Buxus sp. & Buxaceae \\
\hline 50 & Vatairea $s p$. & Papilionaceae & 115 & Erythrophleum sp. & Caesalpiniaceae \\
\hline 51 & Hieronyma sp. & Euphorbiaceae & 116 & $\begin{array}{c}\text { Anadenanthera } \\
\text { macrocarpa }\end{array}$ & Mimosoideae \\
\hline 52 & Fagus sylvatica & Fagaceae & 117 & Chlorophora sp. & Moraceae \\
\hline 53 & Erythrophleum fordii & Caesalpiniaceae & 118 & Staudtia sp. & Myristicaceae \\
\hline 54 & Pinus sp. & Pinaceae & 119 & Cynometra sp. & Caesalpiniaceae \\
\hline 55 & Pinus sylvestris & Pinaceae & 120 & $\begin{array}{l}\text { Swartzia } \\
\text { leiocalycina }\end{array}$ & Papilionaceae \\
\hline 56 & Pinus sp. & Pinaceae & 121 & Baphia kirkii & Papilionaceae \\
\hline 57 & Pseudotsuga sp. & Pinaceae & 122 & Dalbergia cearensis & Papilionaceae \\
\hline 58 & Tsuga sp. & Pinaceae & 123 & $\begin{array}{l}\text { Dalbergia } \\
\text { tucurensis }\end{array}$ & Papilionaceae \\
\hline 59 & Pinus radiata & Pinaceae & 124 & Acer sp. & Aceraceae \\
\hline 60 & Litchi chinensis & Sapindaceae & 125 & Dipterocarpus sp. & Dipterocarpaceae \\
\hline 61 & Euphoria longan & Sapindaceae & 126 & $\begin{array}{c}\text { Liriodendron } \\
\text { tulipifera }\end{array}$ & Magnoliaceae \\
\hline 62 & Cinnamomum sp. & Lauraceae & 127 & Michelia sp. & Magnoliaceae \\
\hline 63 & Daniellia sp. & Caesalpiniaceae & 128 & Palaquium sp. & Sapotaceae \\
\hline 64 & Aquilaria sp. & Thymelaeaceae & 129 & Acacia sp. & Mimosoideae \\
\hline 65 & $\begin{array}{l}\text { Cylicodiscus } \\
\text { gabunensis }\end{array}$ & Mimosoideae & 130 & Toona sinensis & Meliaceae \\
\hline
\end{tabular}


Table S2. Listing of Density, Function Coefficient, Parallel Thermal Conductivity, and Perpendicular Thermal Conductivity

\begin{tabular}{|c|c|c|c|c|c|c|}
\hline No. & Latin name & $\begin{array}{l}\text { Density } \\
\left(\mathrm{g} / \mathrm{cm}^{3}\right)\end{array}$ & $\begin{array}{c}\text { Function } \\
\text { coefficient } \\
\text { (gradient } \\
\text { term A) } \\
\end{array}$ & $\begin{array}{c}\text { Function } \\
\text { coefficient } \\
\text { (gradient term } \\
\text { B) } \\
\end{array}$ & $\begin{array}{c}\text { Parallel } \\
\text { conduct. } \\
(\mathrm{W} / \mathrm{mK})\end{array}$ & $\begin{array}{c}\text { Perpend. } \\
\text { conduct. } \\
\text { (W/mk) }\end{array}$ \\
\hline 1 & Pterocarpus macrocarpus & 1.165171 & 0.618300 & -0.017000 & 0.161854 & 0.432371 \\
\hline 1 & Pterocarpus macrocarpus & 1.165171 & 0.619800 & -0.011800 & 0.155029 & 0.446106 \\
\hline 1 & Pterocarpus macrocarpus & 1.165171 & 0.621300 & -0.007700 & 0.159181 & 0.434052 \\
\hline 2 & Pterocarpus pedatus & 1.102950 & 0.597300 & 0.316700 & 0.126526 & 0.576902 \\
\hline 2 & Pterocarpus pedatus & 1.102950 & 0.604500 & 0.292600 & 0.135651 & 0.533575 \\
\hline 2 & Pterocarpus pedatus & 1.102950 & 0.610100 & 0.291200 & 0.135282 & 0.527667 \\
\hline 3 & Pterocarpus erinaceus & 0.928731 & 0.579100 & 0.221200 & 0.183496 & 0.431954 \\
\hline 3 & Pterocarpus erinaceus & 0.928731 & 0.585700 & 0.190300 & 0.195902 & 0.400747 \\
\hline 3 & Pterocarpus erinaceus & 0.928731 & 0.589000 & 0.174700 & 0.190493 & 0.405785 \\
\hline 4 & Dalbergia latifolia & 0.919562 & 0.623400 & 0.397700 & 0.202100 & 0.343478 \\
\hline 4 & Dalbergia latifolia & 0.919562 & 0.620300 & 0.443500 & 0.200035 & 0.349706 \\
\hline 4 & Dalbergia latifolia & 0.919562 & 0.626200 & 0.427900 & 0.202559 & 0.339315 \\
\hline 5 & $\begin{array}{l}\text { Dalbergia frutescens var. } \\
\text { tomentosa }\end{array}$ & 1.302713 & 0.492500 & 0.069900 & 0.200076 & 0.549978 \\
\hline 5 & $\begin{array}{l}\text { Dalbergia frutescens var. } \\
\text { tomentosa }\end{array}$ & 1.302713 & 0.495800 & 0.062700 & 0.186524 & 0.573295 \\
\hline 5 & $\begin{array}{l}\text { Dalbergia frutescens var. } \\
\text { tomentosa }\end{array}$ & 1.302713 & 0.497700 & 0.064600 & 0.186792 & 0.570284 \\
\hline 6 & Pterocarpus indicus & 0.447992 & 1.115300 & -0.338500 & 0.086823 & 0.240520 \\
\hline 6 & Pterocarpus indicus & 0.447992 & 1.119200 & -0.342300 & 0.093358 & 0.226009 \\
\hline 6 & Pterocarpus indicus & 0.447992 & 1.121300 & -0.352300 & 0.088745 & 0.234749 \\
\hline 7 & Dalbergia melanoxylon & 1.212328 & 0.446600 & -0.337000 & 0.355354 & 0.386427 \\
\hline 7 & Dalbergia melanoxylon & 1.212328 & 0.446700 & -0.340800 & 0.340824 & 0.401112 \\
\hline 7 & Dalbergia melanoxylon & 1.212328 & 0.444500 & -0.345300 & 0.339145 & 0.407174 \\
\hline 8 & Dalbergia cochinchinensis & 1.206870 & 0.484000 & 0.187400 & 0.294592 & 0.393226 \\
\hline 8 & Dalbergia cochinchinensis & 1.206870 & 0.481100 & 0.147100 & 0.279869 & 0.415921 \\
\hline 8 & Dalbergia cochinchinensis & 1.206870 & 0.482900 & 0.095000 & 0.290005 & 0.400216 \\
\hline 9 & Dalbergia bariensis & 1.109172 & 0.481500 & 0.051800 & 0.292508 & 0.396600 \\
\hline
\end{tabular}




\begin{tabular}{|c|c|c|c|c|c|c|}
\hline 9 & Dalbergia bariensis & 1.109172 & 0.482600 & 0.098700 & 0.293197 & 0.394006 \\
\hline 9 & Dalbergia bariensis & 1.109172 & 0.485200 & 0.059700 & 0.296942 & 0.386043 \\
\hline 10 & Dalbergia oliveri & 1.029013 & 0.551800 & -0.147500 & 0.252634 & 0.354907 \\
\hline 10 & Dalbergia oliveri & 1.029013 & 0.550000 & -0.133500 & 0.258457 & 0.349730 \\
\hline 10 & Dalbergia oliveri & 1.029013 & 0.549300 & -0.106800 & 0.250210 & 0.359739 \\
\hline 11 & Dalbergia retusa & 1.111832 & 0.520400 & -0.055800 & 0.263943 & 0.379434 \\
\hline 11 & Dalbergia retusa & 1.111832 & 0.520700 & -0.047200 & 0.262607 & 0.381018 \\
\hline 11 & Dalbergia retusa & 1.111832 & 0.520900 & -0.045200 & 0.268553 & 0.374366 \\
\hline 12 & Millettia stuhlmannii & 0.704358 & 0.629400 & 0.238500 & 0.231822 & 0.293131 \\
\hline 12 & Millettia stuhlmannii & 0.704358 & 0.627700 & 0.258800 & 0.229216 & 0.297553 \\
\hline 12 & Millettia stuhlmannii & 0.704358 & 0.627500 & 0.272100 & 0.229516 & 0.297397 \\
\hline 13 & Dalbergia louvelii & 0.891003 & 0.541400 & 0.354700 & 0.293332 & 0.317385 \\
\hline 13 & Dalbergia louvelii & 0.891003 & 0.539300 & 0.365600 & 0.283237 & 0.329343 \\
\hline 13 & Dalbergia louvelii & 0.891003 & 0.538900 & 0.374700 & 0.279472 & 0.334545 \\
\hline 14 & Dalbergia cultrata & 0.982438 & 0.528000 & 0.460500 & 0.209495 & 0.462264 \\
\hline 14 & Dalbergia cultrata & 0.982438 & 0.525800 & 0.457600 & 0.216793 & 0.451862 \\
\hline 14 & Dalbergia cultrata & 0.982438 & 0.516000 & 0.502800 & 0.192974 & 0.519831 \\
\hline 15 & Diospyros celebica & 1.002307 & 0.523100 & 0.473900 & 0.191892 & 0.508537 \\
\hline 15 & Diospyros celebica & 1.002307 & 0.538700 & 0.363600 & 0.205341 & 0.453025 \\
\hline 15 & Diospyros celebica & 1.002307 & 0.549000 & 0.243900 & 0.223425 & 0.405447 \\
\hline 16 & Cassia siamea & 1.040916 & 0.428300 & 0.025600 & 0.337041 & 0.450427 \\
\hline 16 & Cassia siamea & 1.040916 & 0.423600 & 0.049700 & 0.342502 & 0.442231 \\
\hline 16 & Cassia siamea & 1.040916 & 0.423900 & 0.054600 & 0.367169 & 0.415692 \\
\hline 17 & Baphia nitida & 1.285356 & 0.423700 & -0.117800 & 0.322692 & 0.472019 \\
\hline 17 & Baphia nitida & 1.285356 & 0.424200 & -0.120200 & 0.327810 & 0.463150 \\
\hline 17 & Baphia nitida & 1.285356 & 0.424400 & -0.114600 & 0.326353 & 0.464167 \\
\hline 18 & Bulnesia sp. & 0.860297 & 0.604800 & -0.512900 & 0.229640 & 0.323331 \\
\hline 18 & Bulnesia sp. & 0.860297 & 0.602500 & -0.512200 & 0.229348 & 0.327073 \\
\hline 18 & Bulnesia sp. & 0.860297 & 0.602300 & -0.487000 & 0.227833 & 0.329218 \\
\hline 19 & Cordia sp. & 0.987425 & 0.516200 & 0.098400 & 0.609024 & 0.168040 \\
\hline 19 & Cordia sp. & 0.987425 & 0.516600 & 0.099700 & 0.576984 & 0.176316 \\
\hline 19 & Cordia sp. & 0.987425 & 0.516600 & 0.122900 & 0.601212 & 0.170123 \\
\hline 20 & Combretum imberbe & 1.228766 & 0.441600 & -0.232800 & 0.567351 & 0.245577 \\
\hline 20 & Combretum imberbe & 1.228766 & 0.439900 & -0.201100 & 0.588419 & 0.239569 \\
\hline 20 & Combretum imberbe & 1.228766 & 0.439900 & -0.179100 & 0.571114 & 0.247132 \\
\hline 21 & Swartzia madagascariensis & 1.083138 & 0.481300 & 0.493700 & 0.465255 & 0.250270 \\
\hline
\end{tabular}




\begin{tabular}{|c|c|c|c|c|c|c|}
\hline 21 & Swartzia madagascariensis & 1.083138 & 0.481300 & 0.493000 & 0.468362 & 0.248175 \\
\hline 21 & Swartzia madagascariensis & 1.083138 & 0.482800 & 0.490400 & 0.465004 & 0.248877 \\
\hline 22 & Ulmus sp. & 0.507920 & 0.979100 & -0.381200 & 0.212949 & 0.132173 \\
\hline 22 & Ulmus sp. & 0.507920 & 0.974400 & -0.366600 & 0.207972 & 0.135876 \\
\hline 22 & Ulmus sp. & 0.507920 & 0.973500 & -0.361200 & 0.203419 & 0.138670 \\
\hline 23 & Pterocarpus tinctorius & 0.992981 & 0.540700 & 0.178900 & 0.377942 & 0.244073 \\
\hline 23 & Pterocarpus tinctorius & 0.992981 & 0.540700 & 0.183500 & 0.377160 & 0.244513 \\
\hline 23 & Pterocarpus tinctorius & 0.992981 & 0.540800 & 0.188500 & 0.377713 & 0.243997 \\
\hline 24 & Colophospermum mopane & 1.297750 & 0.433200 & -0.093800 & 0.414519 & 0.351685 \\
\hline 24 & Colophospermum mopane & 1.297750 & 0.431300 & -0.080100 & 0.397757 & 0.369210 \\
\hline 24 & Colophospermum mopane & 1.297750 & 0.430800 & -0.076200 & 0.398090 & 0.369766 \\
\hline 25 & Gluta $s p$. & 0.827704 & 0.617800 & -0.149700 & 0.390349 & 0.181512 \\
\hline 25 & Gluta sp. & 0.827704 & 0.616000 & -0.150500 & 0.392499 & 0.181783 \\
\hline 25 & Gluta $s p$. & 0.827704 & 0.615500 & -0.140000 & 0.392814 & 0.182387 \\
\hline 26 & Streblus sp. & 1.074903 & 0.490600 & 0.000700 & 0.307764 & 0.366963 \\
\hline 26 & Streblus sp. & 1.074903 & 0.487700 & 0.026400 & 0.306516 & 0.372701 \\
\hline 26 & Streblus sp. & 1.074903 & 0.486800 & 0.015100 & 0.296193 & 0.384275 \\
\hline 27 & Phoebe sp. & 0.525604 & 0.981300 & -0.387300 & 0.122730 & 0.225797 \\
\hline 27 & Phoebe sp. & 0.525604 & 0.975400 & -0.381500 & 0.121518 & 0.229888 \\
\hline 27 & Phoebe sp. & 0.525604 & 0.974300 & -0.370500 & 0.118499 & 0.235295 \\
\hline 28 & Platycladus orientalis & 0.735277 & 0.622500 & -0.062500 & 0.476453 & 0.147375 \\
\hline 28 & Platycladus orientalis & 0.735277 & 0.622200 & -0.048000 & 0.460912 & 0.152735 \\
\hline 28 & Platycladus orientalis & 0.735277 & 0.621900 & -0.041300 & 0.465912 & 0.151491 \\
\hline 29 & Lindera sp. & 0.721878 & 0.628100 & 0.232100 & 0.416335 & 0.164444 \\
\hline 29 & Lindera sp. & 0.721878 & 0.629800 & 0.226800 & 0.425144 & 0.160477 \\
\hline 29 & Lindera sp. & 0.721878 & 0.631200 & 0.223400 & 0.404970 & 0.166793 \\
\hline 30 & Myroxylon balsamum & 0.939866 & 0.518800 & 0.556400 & 0.590882 & 0.170246 \\
\hline 30 & Myroxylon balsamum & 0.939866 & 0.519500 & 0.556000 & 0.558872 & 0.177710 \\
\hline 30 & Myroxylon balsamum & 0.939866 & 0.519700 & 0.553800 & 0.585200 & 0.170566 \\
\hline 31 & Guibourtia tessmannii & 0.805228 & 0.598500 & -0.203600 & 0.473571 & 0.159659 \\
\hline 31 & Guibourtia tessmannii & 0.805228 & 0.599500 & -0.229300 & 0.483411 & 0.156683 \\
\hline 31 & Guibourtia tessmannii & 0.805228 & 0.599500 & -0.225400 & 0.474448 & 0.158878 \\
\hline 32 & Pterocarpus soyauxii & 0.729505 & 0.664900 & -0.154700 & 0.356234 & 0.169853 \\
\hline
\end{tabular}




\begin{tabular}{|c|c|c|c|c|c|c|}
\hline 32 & Pterocarpus soyauxii & 0.729505 & 0.670200 & -0.163500 & 0.351205 & 0.169085 \\
\hline 32 & Pterocarpus soyauxii & 0.729505 & 0.672800 & -0.172300 & 0.355554 & 0.165925 \\
\hline 33 & Microberlinia sp. & 0.909226 & 0.524300 & -0.230000 & 0.634575 & 0.153207 \\
\hline 33 & Microberlinia sp. & 0.909226 & 0.524000 & -0.227500 & 0.625293 & 0.155393 \\
\hline 33 & Microberlinia sp. & 0.909226 & 0.522700 & -0.181900 & 0.619872 & 0.157165 \\
\hline 34 & Paraberlinia bifoliolata & 0.676283 & 0.540700 & -0.194000 & 0.563798 & 0.164840 \\
\hline 34 & Paraberlinia bifoliolata & 0.676283 & 0.537800 & -0.193600 & 0.573171 & 0.164614 \\
\hline 34 & Paraberlinia bifoliolata & 0.676283 & 0.536600 & -0.200800 & 0.575657 & 0.164661 \\
\hline 35 & Intsia sp. & 0.901845 & 0.581400 & -0.305500 & 0.549891 & 0.146972 \\
\hline 35 & Intsia sp. & 0.901845 & 0.580800 & -0.289400 & 0.537605 & 0.149921 \\
\hline 35 & Intsia sp. & 0.901845 & 0.581400 & -0.278100 & 0.537056 & 0.149693 \\
\hline 36 & Tectona grandis & 0.686852 & 0.734400 & -0.633500 & 0.381557 & 0.132480 \\
\hline 36 & Tectona grandis & 0.686852 & 0.732000 & -0.628200 & 0.379527 & 0.134080 \\
\hline 36 & Tectona grandis & 0.686852 & 0.731400 & -0.590900 & 0.370113 & 0.137436 \\
\hline 37 & Peltogyne sp. & 1.168446 & 0.438300 & 0.241400 & 0.444329 & 0.316106 \\
\hline 37 & Peltogyne sp. & 1.168446 & 0.437800 & 0.295800 & 0.430290 & 0.324053 \\
\hline 37 & Peltogyne sp. & 1.168446 & 0.437700 & 0.295800 & 0.435110 & 0.322261 \\
\hline 38 & $\begin{array}{l}\text { Entandrophragma } \\
\text { cylindricum }\end{array}$ & 0.741889 & 0.662100 & -0.070500 & 0.306886 & 0.199311 \\
\hline 38 & $\begin{array}{l}\text { Entandrophragma } \\
\text { cylindricum }\end{array}$ & 0.741889 & 0.663400 & -0.063400 & 0.309998 & 0.197215 \\
\hline 38 & $\begin{array}{l}\text { Entandrophragma } \\
\text { cylindricum }\end{array}$ & 0.741889 & 0.664200 & -0.050000 & 0.311907 & 0.195823 \\
\hline 39 & Mangifera sp. & 0.639062 & 0.798800 & 0.150600 & 0.140295 & 0.297228 \\
\hline 39 & Mangifera sp. & 0.639062 & 0.797800 & 0.158800 & 0.147250 & 0.286109 \\
\hline 39 & Mangifera sp. & 0.639062 & 0.798600 & 0.153000 & 0.141898 & 0.295397 \\
\hline 40 & Lophira alata & 0.941912 & 0.544900 & 0.364600 & 0.499367 & 0.183433 \\
\hline 40 & Lophira alata & 0.941912 & 0.542300 & 0.381600 & 0.499316 & 0.185917 \\
\hline 40 & Lophira alata & 0.941912 & 0.542200 & 0.380500 & 0.497418 & 0.186145 \\
\hline 41 & Fraxinus $s p$. & 0.665602 & 0.705900 & -0.217500 & 0.162172 & 0.327200 \\
\hline 41 & Fraxinus sp. & 0.665602 & 0.704100 & -0.195700 & 0.160910 & 0.331019 \\
\hline 41 & Fraxinus sp. & 0.665602 & 0.703500 & -0.192200 & 0.167996 & 0.319902 \\
\hline 42 & Fraxinus mandshurica & 0.577673 & 0.946600 & -0.313100 & 0.102602 & 0.288487 \\
\hline 42 & Fraxinus mandshurica & 0.577673 & 0.942800 & -0.308300 & 0.104438 & 0.287049 \\
\hline 42 & Fraxinus mandshurica & 0.577673 & 0.941800 & -0.302000 & 0.103875 & 0.289129 \\
\hline 43 & Quercus sp. & 0.747687 & 0.603000 & 0.701000 & 0.267280 & 0.276848 \\
\hline 43 & Quercus sp. & 0.747687 & 0.601500 & 0.710300 & 0.251895 & 0.292222 \\
\hline 43 & Quercus sp. & 0.747687 & 0.600700 & 0.717900 & 0.257163 & 0.287863 \\
\hline
\end{tabular}




\begin{tabular}{|c|c|c|c|c|c|c|}
\hline 44 & Quercus sp. & 0.576364 & 0.822100 & -0.217500 & 0.146048 & 0.272421 \\
\hline 44 & Quercus sp. & 0.576364 & 0.819500 & -0.192900 & 0.140659 & 0.282038 \\
\hline 44 & Quercus sp. & 0.576364 & 0.818800 & -0.201200 & 0.139954 & 0.284770 \\
\hline 45 & Caesalpinia paraguariensis & 1.107699 & 0.456900 & -0.037700 & 0.324405 & 0.402546 \\
\hline 45 & Caesalpinia paraguariensis & 1.107699 & 0.456200 & -0.039200 & 0.327469 & 0.401155 \\
\hline 45 & Caesalpinia paraguariensis & 1.107699 & 0.454800 & -0.040000 & 0.322830 & 0.407661 \\
\hline 46 & Juglans sp. & 0.673362 & 0.740400 & -0.124700 & 0.186434 & 0.265836 \\
\hline 46 & Juglans sp. & 0.673362 & 0.736700 & -0.105800 & 0.179454 & 0.276921 \\
\hline 46 & Juglans sp. & 0.673362 & 0.735900 & -0.103600 & 0.184797 & 0.271398 \\
\hline 47 & Dipteryx sp. & 0.987204 & 0.463600 & 0.250100 & 0.421900 & 0.298544 \\
\hline 47 & Dipteryx sp. & 0.987204 & 0.460700 & 0.257300 & 0.403784 & 0.313720 \\
\hline 47 & Dipteryx sp. & 0.987204 & 0.459300 & 0.258800 & 0.409781 & 0.312514 \\
\hline 48 & Bombax sp. & 0.518998 & 0.992000 & -0.608800 & 0.105173 & 0.256243 \\
\hline 48 & Bombax sp. & 0.518998 & 0.992600 & -0.646300 & 0.106220 & 0.254233 \\
\hline 48 & Bombax sp. & 0.518998 & 0.994400 & -0.651800 & 0.105624 & 0.255607 \\
\hline 49 & Buchenavia sp. & 0.681548 & 0.733400 & 0.003900 & 0.165903 & 0.299841 \\
\hline 49 & Buchenavia sp. & 0.681548 & 0.732400 & 0.007200 & 0.170413 & 0.294427 \\
\hline 49 & Buchenavia sp. & 0.681548 & 0.732900 & 0.002700 & 0.171532 & 0.292437 \\
\hline 50 & Vatairea sp. & 0.867096 & 0.647000 & -0.054500 & 0.195592 & 0.329352 \\
\hline 50 & Vatairea sp. & 0.867096 & 0.644000 & -0.042400 & 0.187906 & 0.343531 \\
\hline 50 & Vatairea sp. & 0.867096 & 0.642900 & -0.026000 & 0.188234 & 0.344199 \\
\hline 51 & Hieronyma sp. & 0.811421 & 0.663800 & -0.115000 & 0.185556 & 0.330955 \\
\hline 51 & Hieronyma sp. & 0.811421 & 0.663300 & -0.109900 & 0.183008 & 0.334187 \\
\hline 51 & Hieronyma sp. & 0.811421 & 0.664100 & -0.095500 & 0.187891 & 0.327057 \\
\hline 52 & Fagus sylvatica & 0.764708 & 0.652300 & 0.187000 & 0.163120 & 0.379943 \\
\hline 52 & Fagus sylvatica & 0.764708 & 0.651700 & 0.184800 & 0.166327 & 0.373473 \\
\hline 52 & Fagus sylvatica & 0.764708 & 0.651700 & 0.187100 & 0.164552 & 0.376757 \\
\hline 53 & Erythrophleum fordii & 0.989414 & 0.501100 & 0.379700 & 0.286028 & 0.379769 \\
\hline 53 & Erythrophleum fordii & 0.989414 & 0.500000 & 0.386700 & 0.289418 & 0.376531 \\
\hline 53 & Erythrophleum fordii & 0.989414 & 0.500300 & 0.381700 & 0.283669 & 0.383283 \\
\hline 54 & Pinus sp. & 0.478365 & 0.956300 & -0.425200 & 0.158022 & 0.187301 \\
\hline 54 & Pinus sp. & 0.478365 & 0.953000 & -0.428900 & 0.158341 & 0.188216 \\
\hline 54 & Pinus sp. & 0.478365 & 0.952800 & -0.410100 & 0.153720 & 0.193617 \\
\hline 55 & Pinus sylvestris & 0.531608 & 0.887700 & -0.165300 & 0.148717 & 0.227529 \\
\hline 55 & Pinus sylvestris & 0.531608 & 0.884700 & -0.134000 & 0.144614 & 0.233700 \\
\hline
\end{tabular}




\begin{tabular}{|c|c|c|c|c|c|c|}
\hline 55 & Pinus sylvestris & 0.531608 & 0.884200 & -0.106100 & 0.146604 & 0.231999 \\
\hline 56 & Pinus sp. & 0.653822 & 0.799400 & -0.304500 & 0.156493 & 0.269121 \\
\hline 56 & Pinus sp. & 0.653822 & 0.797500 & -0.299400 & 0.158013 & 0.267464 \\
\hline 56 & Pinus sp. & 0.653822 & 0.796900 & -0.303200 & 0.158650 & 0.267226 \\
\hline 57 & Pseudotsuga sp. & 0.452062 & 1.056500 & -0.034500 & 0.102312 & 0.230175 \\
\hline 57 & Pseudotsuga sp. & 0.452062 & 1.050100 & -0.018100 & 0.100422 & 0.236348 \\
\hline 57 & Pseudotsuga sp. & 0.452062 & 1.048900 & -0.002300 & 0.099825 & 0.237874 \\
\hline 58 & Tsuga sp. & 0.386462 & 1.294600 & -0.364400 & 0.076975 & 0.204913 \\
\hline 58 & Tsuga sp. & 0.386462 & 1.287400 & -0.337400 & 0.078013 & 0.205244 \\
\hline 58 & Tsuga sp. & 0.386462 & 1.285200 & -0.332600 & 0.075482 & 0.211044 \\
\hline 59 & Pinus radiata & 0.426624 & 0.917800 & 0.107900 & 0.158625 & 0.215889 \\
\hline 59 & Pinus radiata & 0.426624 & 0.912300 & 0.126700 & 0.152820 & 0.220610 \\
\hline 59 & Pinus radiata & 0.426624 & 0.909800 & 0.136200 & 0.185939 & 0.185502 \\
\hline 60 & Litchi chinensis & 0.865412 & 0.571100 & 0.359600 & 0.515161 & 0.163573 \\
\hline 60 & Litchi chinensis & 0.865412 & 0.569100 & 0.320300 & 0.524361 & 0.161631 \\
\hline 60 & Litchi chinensis & 0.865412 & 0.569100 & 0.325300 & 0.531801 & 0.159026 \\
\hline 61 & Euphoria longan & 0.874470 & 0.577200 & 0.836700 & 0.447850 & 0.181437 \\
\hline 61 & Euphoria longan & 0.874470 & 0.579100 & 0.855300 & 0.450539 & 0.179422 \\
\hline 61 & Euphoria longan & 0.874470 & 0.581100 & 0.892700 & 0.434954 & 0.183783 \\
\hline 62 & Cinnamomum sp. & 0.631014 & 0.737700 & -0.079000 & 0.273697 & 0.181002 \\
\hline 62 & Cinnamomum sp. & 0.631014 & 0.743900 & -0.087800 & 0.281624 & 0.173678 \\
\hline 62 & Cinnamomum sp. & 0.631014 & 0.747300 & -0.086700 & 0.289524 & 0.167803 \\
\hline 63 & Daniellia sp. & 0.525293 & 0.928600 & 0.154200 & 0.134436 & 0.227641 \\
\hline 63 & Daniellia sp. & 0.525293 & 0.927000 & 0.172600 & 0.136329 & 0.228070 \\
\hline 63 & Daniellia $s p$. & 0.525293 & 0.926400 & 0.179400 & 0.135985 & 0.228828 \\
\hline 64 & Aquilaria sp. & 0.342625 & 1.305200 & -0.519900 & 0.065463 & 0.236521 \\
\hline 64 & Aquilaria sp. & 0.342625 & 1.299400 & -0.504200 & 0.065003 & 0.240161 \\
\hline 64 & Aquilaria sp. & 0.342625 & 1.298800 & -0.492100 & 0.063606 & 0.244507 \\
\hline 65 & Cylicodiscus gabunensis & 0.838227 & 0.597900 & 0.329500 & 0.497513 & 0.151014 \\
\hline 65 & Cylicodiscus gabunensis & 0.838227 & 0.599100 & 0.324100 & 0.498026 & 0.150112 \\
\hline 65 & Cylicodiscus gabunensis & 0.838227 & 0.600100 & 0.327600 & 0.502603 & 0.148604 \\
\hline 66 & Khaya sp. & 0.834070 & 0.615500 & 0.239100 & 0.193305 & 0.370173 \\
\hline 66 & Khaya sp. & 0.834070 & 0.612300 & 0.242700 & 0.186921 & 0.385277 \\
\hline 66 & Khaya sp. & 0.834070 & 0.611400 & 0.245100 & 0.191201 & 0.378844 \\
\hline 67 & Eusideroxylon zwageri & 0.979415 & 0.485100 & 0.445300 & 0.286687 & 0.403248 \\
\hline 67 & Eusideroxylon zwageri & 0.979415 & 0.486000 & 0.431400 & 0.291831 & 0.394354 \\
\hline 67 & Eusideroxylon zwageri & 0.979415 & 0.488700 & 0.420800 & 0.296161 & 0.384380 \\
\hline 68 & Spirostachys africana & 0.989715 & 0.539100 & -0.002500 & 0.313044 & 0.299917 \\
\hline
\end{tabular}




\begin{tabular}{|c|c|c|c|c|c|c|}
\hline 68 & Spirostachys africana & 0.989715 & 0.537600 & 0.001600 & 0.302798 & 0.310832 \\
\hline 68 & Spirostachys africana & 0.989715 & 0.537500 & 0.003200 & 0.306778 & 0.306859 \\
\hline 69 & Guibourtia conjugata & 1.084004 & 0.457600 & -0.096100 & 0.384623 & 0.338527 \\
\hline 69 & Guibourtia conjugata & 1.084004 & 0.456700 & -0.100700 & 0.381157 & 0.342777 \\
\hline 69 & Guibourtia conjugata & 1.084004 & 0.457000 & -0.095000 & 0.378836 & 0.345324 \\
\hline 70 & Terminalia sp. & 0.476664 & 1.015100 & -0.644800 & 0.130715 & 0.198399 \\
\hline 70 & Terminalia sp. & 0.476664 & 1.012400 & -0.690200 & 0.128557 & 0.202408 \\
\hline 70 & Terminalia sp. & 0.476664 & 1.013400 & -0.685400 & 0.129360 & 0.201078 \\
\hline 71 & Triplochiton scleroxylon & 0.294327 & 1.417400 & -0.547800 & 0.030682 & 0.422248 \\
\hline 71 & Triplochiton scleroxylon & 0.294327 & 1.412400 & -0.523100 & 0.030837 & 0.423086 \\
\hline 71 & Triplochiton scleroxylon & 0.294327 & 1.412400 & -0.526900 & 0.030157 & 0.432364 \\
\hline 72 & Dryobalanops sp. & 0.653053 & 0.820700 & 0.337600 & 0.107503 & 0.373806 \\
\hline 72 & Dryobalanops sp. & 0.653053 & 0.815100 & 0.360300 & 0.104982 & 0.386938 \\
\hline 72 & Dryobalanops sp. & 0.653053 & 0.813600 & 0.370500 & 0.101882 & 0.398209 \\
\hline 73 & Berlinia sp. & 0.673009 & 0.816700 & -0.070200 & 0.081968 & 0.476651 \\
\hline 73 & Berlinia sp. & 0.673009 & 0.815400 & -0.065600 & 0.080330 & 0.485764 \\
\hline 73 & Berlinia sp. & 0.673009 & 0.815700 & -0.065500 & 0.080584 & 0.484326 \\
\hline 74 & Koompassia sp. & 0.919015 & 0.557500 & 0.063000 & 0.204677 & 0.425149 \\
\hline 74 & Koompassia sp. & 0.919015 & 0.554900 & 0.066600 & 0.200009 & 0.437072 \\
\hline 74 & Koompassia sp. & 0.919015 & 0.554600 & 0.060400 & 0.201790 & 0.433320 \\
\hline 75 & Hevea brasiliensis & 0.729811 & 0.707600 & 0.032100 & 0.155545 & 0.347050 \\
\hline 75 & Hevea brasiliensis & 0.729811 & 0.704100 & 0.044100 & 0.150145 & 0.360980 \\
\hline 75 & Hevea brasiliensis & 0.729811 & 0.695100 & 0.068400 & 0.142357 & 0.386808 \\
\hline 76 & Aucoumea klaineana & 0.480767 & 0.911500 & -0.409700 & 0.134792 & 0.240608 \\
\hline 76 & Aucoumea klaineana & 0.480767 & 0.907800 & -0.386200 & 0.134135 & 0.242808 \\
\hline 76 & Aucoumea klaineana & 0.480767 & 0.907100 & -0.358500 & 0.130825 & 0.249668 \\
\hline 77 & Calophyllum sp. & 0.767951 & 0.688300 & 0.337500 & 0.225691 & 0.254496 \\
\hline 77 & Calophyllum sp. & 0.767951 & 0.685000 & 0.344100 & 0.223241 & 0.258571 \\
\hline 77 & Calophyllum sp. & 0.767951 & 0.684400 & 0.347400 & 0.222262 & 0.260136 \\
\hline 78 & Excentrodendron hsienmu & 0.967439 & 0.445300 & 0.729200 & 0.498767 & 0.268891 \\
\hline 78 & Excentrodendron hsienmu & 0.967439 & 0.448800 & 0.712400 & 0.511882 & 0.259351 \\
\hline 78 & Excentrodendron hsienmu & 0.967439 & 0.450900 & 0.694100 & 0.512827 & 0.256615 \\
\hline 79 & Pericopsis elata & 0.659547 & 0.728500 & 0.064100 & 0.178374 & 0.286079 \\
\hline 79 & Pericopsis elata & 0.659547 & 0.723700 & 0.065900 & 0.177868 & 0.291264 \\
\hline 79 & Pericopsis elata & 0.659547 & 0.722100 & 0.072700 & 0.169415 & 0.304472 \\
\hline
\end{tabular}




\begin{tabular}{|c|c|c|c|c|c|c|}
\hline 80 & Betula alnoides & 0.691240 & 0.643600 & -0.319700 & 0.227081 & 0.288412 \\
\hline 80 & Betula alnoides & 0.691240 & 0.642300 & -0.360600 & 0.217076 & 0.301826 \\
\hline 80 & Betula alnoides & 0.691240 & 0.642400 & -0.369700 & 0.225371 & 0.292397 \\
\hline 81 & Pterocarpus angolensis & 0.595328 & 0.643600 & -0.319700 & 0.112801 & 0.321098 \\
\hline 81 & Pterocarpus angolensis & 0.595328 & 0.642300 & -0.360600 & 0.112496 & 0.323899 \\
\hline 81 & Pterocarpus angolensis & 0.595328 & 0.642400 & -0.369700 & 0.109509 & 0.331477 \\
\hline 82 & Sindora sp. & 0.623389 & 0.795400 & -0.054200 & 0.162426 & 0.262398 \\
\hline 82 & Sindora $s p$. & 0.623389 & 0.794600 & -0.090500 & 0.163002 & 0.262201 \\
\hline 82 & Sindora sp. & 0.623389 & 0.795100 & -0.098400 & 0.162956 & 0.262154 \\
\hline 83 & Shorea sp. & 0.449577 & 0.916000 & 0.071700 & 0.135095 & 0.235423 \\
\hline 83 & Shorea sp. & 0.449577 & 0.910000 & 0.095000 & 0.133764 & 0.239919 \\
\hline 83 & Shorea sp. & 0.449577 & 0.908800 & 0.112500 & 0.130237 & 0.245437 \\
\hline 84 & Swintonia sp. & 0.871661 & 0.566800 & 0.166100 & 0.225411 & 0.373741 \\
\hline 84 & Swintonia sp. & 0.871661 & 0.563200 & 0.170700 & 0.216391 & 0.391845 \\
\hline 84 & Swintonia sp. & 0.871661 & 0.561500 & 0.174200 & 0.221848 & 0.386181 \\
\hline 85 & Pometia sp. & 0.650265 & 0.875100 & -0.249900 & 0.107120 & 0.324426 \\
\hline 85 & Pometia sp. & 0.650265 & 0.869000 & -0.229900 & 0.102626 & 0.340312 \\
\hline 85 & Pometia sp. & 0.650265 & 0.867200 & -0.215800 & 0.103058 & 0.340469 \\
\hline 86 & Ochroma sp. & 0.227389 & 1.848700 & -0.427400 & 0.045187 & 0.163573 \\
\hline 86 & Ochroma sp. & 0.227389 & 1.720300 & -0.093200 & 0.039499 & 0.202276 \\
\hline 86 & Ochroma sp. & 0.227389 & 1.612200 & 0.178900 & 0.036619 & 0.234925 \\
\hline 87 & Platymiscium sp. & 1.061543 & 0.512500 & 0.133500 & 0.240884 & 0.428739 \\
\hline 87 & Platymiscium sp. & 1.061543 & 0.508800 & 0.140900 & 0.235342 & 0.444772 \\
\hline 87 & Platymiscium sp. & 1.061543 & 0.507200 & 0.134200 & 0.224991 & 0.463766 \\
\hline 88 & Dicorynia sp. & 0.720713 & 0.561800 & 0.139200 & 0.287348 & 0.300849 \\
\hline 88 & Dicorynia sp. & 0.720713 & 0.556100 & 0.164800 & 0.277343 & 0.315991 \\
\hline 88 & Dicorynia sp. & 0.720713 & 0.554300 & 0.171300 & 0.274516 & 0.321603 \\
\hline 89 & Marmaroxylon racemosum & 0.933722 & 0.525800 & 0.837800 & 0.241757 & 0.403719 \\
\hline 89 & Marmaroxylon racemosum & 0.933722 & 0.519600 & 0.867200 & 0.236663 & 0.419308 \\
\hline 89 & Marmaroxylon racemosum & 0.933722 & 0.523300 & 0.849400 & 0.252704 & 0.391712 \\
\hline 90 & Loxopterygium sagotii & 0.754428 & 0.682000 & -0.376700 & 0.183595 & 0.318539 \\
\hline 90 & Loxopterygium sagotii & 0.754428 & 0.678700 & -0.344100 & 0.183316 & 0.321262 \\
\hline 90 & Loxopterygium sagotii & 0.754428 & 0.678400 & -0.309700 & 0.180495 & 0.327625 \\
\hline 91 & Tabebuia sp. & 0.881257 & 0.534700 & 0.365100 & 0.299567 & 0.317376 \\
\hline 91 & Tabebuia sp. & 0.881257 & 0.530300 & 0.386000 & 0.307522 & 0.315799 \\
\hline
\end{tabular}




\begin{tabular}{|c|c|c|c|c|c|c|}
\hline 91 & Tabebuia sp. & 0.881257 & 0.528900 & 0.397900 & 0.300256 & 0.324634 \\
\hline 92 & Andira sp. & 0.765733 & 0.535400 & 0.055900 & 0.332481 & 0.284964 \\
\hline 92 & Andira sp. & 0.765733 & 0.533100 & 0.059600 & 0.327352 & 0.292442 \\
\hline 92 & Andira sp. & 0.765733 & 0.532500 & 0.067400 & 0.327022 & 0.293341 \\
\hline 93 & Humiria balsamifera & 0.794814 & 0.718300 & 0.437000 & 0.143253 & 0.359031 \\
\hline 93 & Humiria balsamifera & 0.794814 & 0.713500 & 0.455100 & 0.139537 & 0.371177 \\
\hline 93 & Humiria balsamifera & 0.794814 & 0.711200 & 0.466200 & 0.142181 & 0.368251 \\
\hline 94 & Diplotropis sp. & 0.814358 & 0.593400 & 0.124200 & 0.229285 & 0.335510 \\
\hline 94 & Diplotropis sp. & 0.814358 & 0.590200 & 0.144300 & 0.222811 & 0.346256 \\
\hline 94 & Diplotropis sp. & 0.814358 & 0.589900 & 0.146700 & 0.222837 & 0.347663 \\
\hline 95 & Brosimum sp. & 0.878494 & 0.566800 & 0.309000 & 0.292391 & 0.290324 \\
\hline 95 & Brosimum sp. & 0.878494 & 0.562700 & 0.320100 & 0.288183 & 0.298616 \\
\hline 95 & Brosimum sp. & 0.878494 & 0.561000 & 0.321700 & 0.281360 & 0.307076 \\
\hline 96 & Martiodendron sp. & 0.880864 & 0.544800 & 1.089200 & 0.264063 & 0.344469 \\
\hline 96 & Martiodendron sp. & 0.880864 & 0.539700 & 1.102800 & 0.263982 & 0.351948 \\
\hline 96 & Martiodendron sp. & 0.880864 & 0.538100 & 1.111600 & 0.268228 & 0.348580 \\
\hline 97 & Vouacapoua americana & 0.942338 & 0.546700 & -0.064900 & 0.218213 & 0.412650 \\
\hline 97 & Vouacapoua americana & 0.942338 & 0.543800 & -0.061600 & 0.222247 & 0.410848 \\
\hline 97 & Vouacapoua americana & 0.942338 & 0.543200 & -0.050800 & 0.217221 & 0.419992 \\
\hline 98 & Manilkara sp. & 0.973081 & 0.557100 & 0.658000 & 0.253659 & 0.345894 \\
\hline 98 & Manilkara sp. & 0.973081 & 0.553000 & 0.672000 & 0.247038 & 0.357864 \\
\hline 98 & Manilkara sp. & 0.973081 & 0.551800 & 0.671800 & 0.237684 & 0.372249 \\
\hline 99 & Platonia insignis & 0.767178 & 0.667300 & -0.245000 & 0.210669 & 0.289081 \\
\hline 99 & Platonia insignis & 0.767178 & 0.662200 & -0.234300 & 0.212701 & 0.291922 \\
\hline 99 & Platonia insignis & 0.767178 & 0.660100 & -0.225900 & 0.204773 & 0.302762 \\
\hline 100 & Hymenaea sp. & 0.794748 & 0.650200 & -0.359500 & 0.187399 & 0.340787 \\
\hline 100 & Hymenaea sp. & 0.794748 & 0.648600 & -0.395400 & 0.185573 & 0.346121 \\
\hline 100 & Hymenaea sp. & 0.794748 & 0.648800 & -0.406100 & 0.185143 & 0.346477 \\
\hline 101 & Diospyros sp. & 0.927915 & 0.617700 & -0.105100 & 0.181763 & 0.389713 \\
\hline 101 & Diospyros sp. & 0.927915 & 0.613100 & -0.087000 & 0.182305 & 0.395038 \\
\hline 101 & Diospyros sp. & 0.927915 & 0.611700 & -0.085600 & 0.180329 & 0.401372 \\
\hline 102 & Prunus sp. & 0.548866 & 0.949500 & -0.311200 & 0.110726 & 0.268363 \\
\hline 102 & Prunus sp. & 0.548866 & 0.941200 & -0.286800 & 0.107469 & 0.279472 \\
\hline 102 & Prunus sp. & 0.548866 & 0.937700 & -0.276800 & 0.103920 & 0.288229 \\
\hline 103 & Xylia sp. & 0.988551 & 0.501900 & 0.133600 & 0.311069 & 0.349481 \\
\hline 103 & Xylia sp. & 0.988551 & 0.497600 & 0.148000 & 0.300697 & 0.365732 \\
\hline 103 & Xylia sp. & 0.988551 & 0.495700 & 0.150800 & 0.305541 & 0.364575 \\
\hline 104 & Terminalia tomentosa & 1.063786 & 0.546000 & -0.119400 & 0.201658 & 0.450593 \\
\hline
\end{tabular}




\begin{tabular}{|c|c|c|c|c|c|c|}
\hline 104 & Terminalia tomentosa & 1.063786 & 0.545700 & -0.165400 & 0.204858 & 0.444925 \\
\hline 104 & Terminalia tomentosa & 1.063786 & 0.546800 & -0.174700 & 0.205030 & 0.442926 \\
\hline 105 & Aglaia sp. & 0.761030 & 0.664200 & -0.101800 & 0.194385 & 0.316354 \\
\hline 105 & Aglaia sp. & 0.761030 & 0.662200 & -0.077000 & 0.193898 & 0.319218 \\
\hline 105 & Aglaia sp. & 0.761030 & 0.662000 & -0.044400 & 0.193121 & 0.320592 \\
\hline 106 & Afzelia sp. & 0.889125 & 0.628200 & -0.205100 & 0.176047 & 0.388489 \\
\hline 106 & Afzelia sp. & 0.889125 & 0.630300 & -0.212200 & 0.178356 & 0.380489 \\
\hline 106 & Afzelia $s p$. & 0.889125 & 0.630700 & -0.211400 & 0.181016 & 0.375500 \\
\hline 107 & Swietenia sp. & 0.480581 & 0.901200 & -0.076700 & 0.119546 & 0.270334 \\
\hline 107 & Swietenia sp. & 0.480581 & 0.896500 & -0.107300 & 0.117223 & 0.278452 \\
\hline 107 & Swietenia sp. & 0.480581 & 0.893500 & -0.103400 & 0.118549 & 0.277659 \\
\hline 108 & Xanthostemon sp. & 1.236086 & 0.420700 & -0.272000 & 0.340130 & 0.454455 \\
\hline 108 & Xanthostemon sp. & 1.236086 & 0.418500 & -0.250700 & 0.331770 & 0.469812 \\
\hline 108 & Xanthostemon sp. & 1.236086 & 0.417900 & -0.219000 & 0.343227 & 0.456330 \\
\hline 109 & Berchemia discolor & 0.955796 & 0.440300 & -0.059100 & 0.343249 & 0.407776 \\
\hline 109 & Berchemia discolor & 0.955796 & 0.441400 & -0.065200 & 0.335285 & 0.416392 \\
\hline 109 & Berchemia discolor & 0.955796 & 0.442500 & -0.055500 & 0.342491 & 0.404910 \\
\hline 110 & Guibourtia coleosperma & 0.961755 & 0.480000 & 0.493800 & 0.247727 & 0.465509 \\
\hline 110 & Guibourtia coleosperma & 0.961755 & 0.485600 & 0.476800 & 0.251969 & 0.449494 \\
\hline 110 & Guibourtia coleosperma & 0.961755 & 0.489200 & 0.473300 & 0.254810 & 0.440842 \\
\hline 111 & Machaerium sp. & 1.036025 & 0.540200 & -0.167800 & 0.257045 & 0.365273 \\
\hline 111 & Machaerium sp. & 1.036025 & 0.536700 & -0.158300 & 0.257025 & 0.369606 \\
\hline 111 & Machaerium sp. & 1.036025 & 0.536800 & -0.153800 & 0.258110 & 0.368141 \\
\hline 112 & Samanea saman & 0.649719 & 0.735000 & -0.223400 & 0.148626 & 0.326778 \\
\hline 112 & Samanea saman & 0.649719 & 0.730000 & -0.233700 & 0.146187 & 0.335043 \\
\hline 112 & Samanea saman & 0.649719 & 0.728700 & -0.243900 & 0.142051 & 0.343955 \\
\hline 113 & Campnosperma sp. & 0.517803 & 0.874900 & -0.212000 & 0.107579 & 0.315994 \\
\hline 113 & Campnosperma sp. & 0.517803 & 0.873000 & -0.200400 & 0.106137 & 0.320752 \\
\hline 113 & Campnosperma sp. & 0.517803 & 0.872300 & -0.210400 & 0.104986 & 0.323791 \\
\hline 114 & Buxus sp. & 0.856124 & 0.540600 & -0.090200 & 0.228593 & 0.402760 \\
\hline 114 & Buxus sp. & 0.856124 & 0.544700 & -0.104000 & 0.227389 & 0.400029 \\
\hline 114 & Buxus sp. & 0.856124 & 0.545600 & -0.100200 & 0.236131 & 0.385738 \\
\hline 115 & Erythrophleum sp. & 0.735967 & 0.555700 & 0.899600 & 0.263818 & 0.330459 \\
\hline 115 & Erythrophleum sp. & 0.735967 & 0.558700 & 0.894300 & 0.258199 & 0.334473 \\
\hline 115 & Erythrophleum sp. & 0.735967 & 0.560600 & 0.886700 & 0.267426 & 0.321362 \\
\hline 116 & Anadenanthera macrocarpa & 0.963992 & 0.468700 & 0.488000 & 0.278381 & 0.438481 \\
\hline
\end{tabular}




\begin{tabular}{|c|c|c|c|c|c|c|}
\hline 116 & Anadenanthera macrocarpa & 0.963992 & 0.470100 & 0.479000 & 0.294035 & 0.415687 \\
\hline 116 & Anadenanthera macrocarpa & 0.963992 & 0.471600 & 0.478800 & 0.298703 & 0.407231 \\
\hline 117 & Chlorophora sp. & 0.658406 & 0.842400 & 0.290700 & 0.092128 & 0.410363 \\
\hline 117 & Chlorophora sp. & 0.658406 & 0.844500 & 0.271500 & 0.091936 & 0.410606 \\
\hline 117 & Chlorophora sp. & 0.658406 & 0.846700 & 0.269100 & 0.093083 & 0.403008 \\
\hline 118 & Staudtia sp. & 0.874887 & 0.658700 & -0.272700 & 0.184866 & 0.339750 \\
\hline 118 & Staudtia sp. & 0.874887 & 0.654100 & -0.298100 & 0.173794 & 0.365157 \\
\hline 118 & Staudtia sp. & 0.874887 & 0.652100 & -0.291100 & 0.176034 & 0.362301 \\
\hline 119 & Cynometra sp. & 0.956749 & 0.535500 & -0.139700 & 0.260568 & 0.363228 \\
\hline 119 & Cynometra sp. & 0.956749 & 0.524600 & -0.094800 & 0.275848 & 0.357458 \\
\hline 119 & Cynometra sp. & 0.956749 & 0.524600 & -0.072500 & 0.283005 & 0.350148 \\
\hline 120 & Swartzia leiocalycina & 1.268000 & 0.398900 & 0.240900 & 0.338884 & 0.498649 \\
\hline 120 & Swartzia leiocalycina & 1.268000 & 0.400200 & 0.247900 & 0.333596 & 0.502014 \\
\hline 120 & Swartzia leiocalycina & 1.268000 & 0.401000 & 0.242800 & 0.317597 & 0.519360 \\
\hline 121 & Baphia kirkii & 1.103675 & 0.419300 & 0.793100 & 0.242629 & 0.598341 \\
\hline 121 & Baphia kirkii & 1.103675 & 0.430100 & 0.764200 & 0.252181 & 0.555863 \\
\hline 121 & Baphia kirkii & 1.103675 & 0.438200 & 0.739900 & 0.281730 & 0.493626 \\
\hline 122 & Dalbergia cearensis & 0.764343 & 0.684800 & 0.188000 & 0.142700 & 0.387019 \\
\hline 122 & Dalbergia cearensis & 0.764343 & 0.694900 & 0.153500 & 0.149112 & 0.364188 \\
\hline 122 & Dalbergia cearensis & 0.764343 & 0.701000 & 0.150800 & 0.153943 & 0.349516 \\
\hline 123 & Dalbergia tucurensis & 0.705964 & 0.664700 & -0.063000 & 0.150726 & 0.385740 \\
\hline 123 & Dalbergia tucurensis & 0.705964 & 0.674300 & -0.094300 & 0.167175 & 0.347733 \\
\hline 123 & Dalbergia tucurensis & 0.705964 & 0.677700 & -0.100500 & 0.169788 & 0.339051 \\
\hline 124 & Acer sp. & 0.653885 & 0.672600 & 0.184900 & 0.173153 & 0.336741 \\
\hline 124 & Acer sp. & 0.653885 & 0.684500 & 0.146900 & 0.183838 & 0.311365 \\
\hline 124 & Acer sp. & 0.653885 & 0.691100 & 0.126100 & 0.184221 & 0.305166 \\
\hline 125 & Dipterocarpus sp. & 1.117999 & 0.511100 & -0.069600 & 0.197430 & 0.519449 \\
\hline 125 & Dipterocarpus sp. & 1.117999 & 0.529400 & -0.121800 & 0.212043 & 0.456446 \\
\hline 125 & Dipterocarpus sp. & 1.117999 & 0.539600 & -0.155700 & 0.215487 & 0.432719 \\
\hline 126 & Liriodendron tulipifera & 0.540571 & 0.876100 & -0.352900 & 0.108838 & 0.312070 \\
\hline 126 & Liriodendron tulipifera & 0.540571 & 0.872300 & -0.387300 & 0.105287 & 0.321855 \\
\hline 126 & Liriodendron tulipifera & 0.540571 & 0.871400 & 0.391600 & 0.105963 & 0.320668 \\
\hline 127 & Michelia sp. & 0.455938 & 0.998100 & -0.181200 & 0.109204 & 0.237761 \\
\hline 127 & Michelia sp. & 0.455938 & 1.001600 & -0.167800 & 0.106548 & 0.241026 \\
\hline 127 & Michelia sp. & 0.455938 & 1.002500 & -0.155300 & 0.107437 & 0.239839 \\
\hline 128 & Palaquium sp. & 0.532069 & 0.973000 & -0.125900 & 0.113845 & 0.243335 \\
\hline
\end{tabular}




\begin{tabular}{|l|c|c|c|c|c|c|}
\hline 128 & Palaquium $s p$. & 0.532069 & 0.983600 & -0.151000 & 0.116823 & 0.234508 \\
\hline 128 & Palaquium $s p$. & 0.532069 & 0.988300 & -0.159600 & 0.116958 & 0.232273 \\
\hline 129 & Acacia $s p$. & 1.034903 & 0.410000 & 0.155400 & 0.212391 & 0.676609 \\
\hline 129 & Acacia $s p$. & 1.034903 & 0.427500 & 0.099300 & 0.258711 & 0.545133 \\
\hline 129 & Acacia $s p$. & 1.034903 & 0.434200 & 0.084600 & 0.262054 & 0.527250 \\
\hline 130 & Toona sinensis & 0.435651 & 1.008600 & -0.087500 & 0.155046 & 0.171287 \\
\hline 130 & Toona sinensis & 0.435651 & 1.014600 & -0.097100 & 0.159820 & 0.164715 \\
\hline 130 & Toona sinensis & 0.435651 & 1.017300 & -0.116100 & 0.156972 & 0.166762 \\
\hline
\end{tabular}

